\title{
Prussian blue iron-cobalt mesocrystals as a template for the growth of Fe/Co carbide (cementite) and Fe/Co nanocrystals.
}

David A. Hardy, ${ }^{1}$ Edward T. Nguyen, ${ }^{1}$ Sara E. Parrish, ${ }^{1}$ Elyse A. Schriber, ${ }^{2}$ Lukas Schlicker, ${ }^{3}$ Albert Gili, ${ }^{3}$ Franz Kamutzki, ${ }^{3}$ J. Nathan Hohman, ${ }^{* 2}$ Geoffrey F. Strouse*1

1) Department of Chemistry and Biochemistry, Florida State University, Tallahassee FL 32306

2) Molecular Foundry and Advanced Light Source, Lawrence Berkeley National Laboratory, One Cyclotron Road, Berkeley, California 94720, United States

3) Fachgebiet Keramische Werkstoffe/Chair of Advanced Ceramic Materials, Institut für Werkstoffwissenschaften und-technologien, Technische Universität Berlin, Hardenbergstraße 40, 10623 Berlin, Germany

* (G.F.S.) Email: strouse@chem.fsu.edu

Supporting Information. 
Supporting Figure 1: a) SEM image of $271+41 \mathrm{~nm} \mathrm{KCo} \operatorname{Kog}_{1.09}\left[\mathrm{Fe}_{0.91}(\mathrm{CN})_{6}\right]$ and b) Gaussian distribution generated by measuring the cube length for $>300$ PBAs........................................ 5 Supporting Figure 2: In-situ high-temperature powder x-ray diffraction patterns from the advanced light source operating at $25 \mathrm{keV}$ of the $\mathrm{H}_{2} \mathrm{O}$ passivated $\mathrm{KCo}_{1.09}\left[\mathrm{Fe}_{0.91}(\mathrm{CN})_{6}\right]$ sample. The heating ramp is $10^{\circ} \mathrm{C} / \mathrm{min}$ from $18{ }^{\circ} \mathrm{C}$ to $600{ }^{\circ} \mathrm{C}$. Data was collected every 34 seconds during the heating ramp. Nitrogen was flowing at a rate of $15 \mathrm{~mL} / \mathrm{min}$ to eliminate oxidization. The blue is the $\mathrm{KCo}_{1.09}\left[\mathrm{Fe}_{0.91}(\mathrm{CN})_{6}\right]$, the magenta traces indicates the phase transition from the cubic to orthorhombic phase, grey trace indicates the orthorhombic phase, dark green indicates disordered phases from the orthorhombic structure to the Fm-3m (high temperature) phase, purple represents the Fm-3m (high temperature) while the light green traces reveal the transition to the $\mathrm{Fe}_{1.30} \mathrm{Co}_{1.70} \mathrm{C}$ phase and black is the $\mathrm{Fe}_{0.97} \mathrm{Co}_{1.03}$. Bolded black traces represent the patterns that were Rietveld refined.

Supporting Figure 3: Rietveld refinement on ALS patterns taken at a) $18{ }^{\circ} \mathrm{C}$, b) $197^{\circ} \mathrm{C}$, and c) $493^{\circ} \mathrm{C}$

Supporting Figure 4: Rietveld refinement of the sample held $197^{\circ} \mathrm{C}$ for $1 \mathrm{hr}$. The sample was run using a Mo $\mathrm{K}_{\alpha}$ anode to reduce the $\mathrm{Fe}$ and Co fluorescence.

Supporting Figure 5: FT-IR showing the M-CN stretch of the $F m-3 m$ (cubic) phase (red trace), OAm passivated $F m-3 m$ (cubic) PBAs (purple trace), and $P m n 2_{1}$ orthorhombic phase (blue trace).

Supporting Figure 6: SEM images of an $\mathrm{H}_{2} \mathrm{O}$ passivated $271+41 \mathrm{~nm} \mathrm{KCo}{ }_{1.09}\left[\mathrm{Fe}_{0.91}(\mathrm{CN})_{6}\right]$ held at $375^{\circ} \mathrm{C}$ for $1 \mathrm{hr}(\mathrm{a}-\mathrm{b})$ and $700{ }^{\circ} \mathrm{C}(\mathrm{d}-\mathrm{e})$. EDX line scans of the material showing the $\mathrm{Fe}$ and $\mathrm{Co}$ signals are displayed in $\mathrm{c}$ and $\mathrm{f}$. TEM images of an OAm passivated $271+41 \mathrm{~nm}$ $\mathrm{KCo}_{1.09}\left[\mathrm{Fe}_{0.91}(\mathrm{CN})_{6}\right]$ held at $375^{\circ} \mathrm{C}$ for $1 \mathrm{hr}(\mathrm{g}-\mathrm{h})$ and $700{ }^{\circ} \mathrm{C}(\mathrm{j}-\mathrm{k})$. EDX line scans of the material showing the $\mathrm{Fe}$ and $\mathrm{Co}$ signals are displayed in $\mathrm{i}$ and $\mathrm{l}$. 11 Supporting Figure 7: TEM images of an $\mathrm{H}_{2} \mathrm{O}$ passivated $271+41 \mathrm{~nm} \mathrm{KCo}{ }_{1.09}\left[\mathrm{Fe}_{0.91}(\mathrm{CN})_{6}\right]$ held at $375^{\circ} \mathrm{C}$ for $1 \mathrm{hr}(\mathrm{a}-\mathrm{b})$ and $700{ }^{\circ} \mathrm{C}(\mathrm{d}-\mathrm{e})$. Distributions of the small material are displayed in $\mathrm{c}$ and f. TEM images of an OAm passivated $271+41 \mathrm{~nm} \mathrm{KCo}{ }_{1.09}\left[\mathrm{Fe}_{0.91}(\mathrm{CN})_{6}\right]$ held at $375^{\circ} \mathrm{C}$ for $1 \mathrm{hr}$ (g-h) and $700{ }^{\circ} \mathrm{C}(\mathrm{j}-\mathrm{k})$. Distributions of the small material are displayed in $\mathrm{i}$ and $1 . . . \ldots \ldots \ldots \ldots \ldots \ldots . . . . .12$

Supporting Figure 8: In-situ high-temperature powder x-ray diffraction patterns from the advanced light source operating at $25 \mathrm{keV}$ of the $\mathrm{OAm}$ passivated $\mathrm{KCo}_{1.09}\left[\mathrm{Fe}_{0.91}(\mathrm{CN})_{6}\right]$ sample. The heating ramp is $10{ }^{\circ} \mathrm{C} / \mathrm{min}$ from $30^{\circ} \mathrm{C}$ to $600^{\circ} \mathrm{C}$. Data was collected every 34 seconds during the heating ramp. Nitrogen was flowing at a rate of $15 \mathrm{~mL} / \mathrm{min}$ to eliminate oxidization. The blue is the $\mathrm{KCo}_{1.09}\left[\mathrm{Fe}_{0.91}(\mathrm{CN})_{6}\right]$, the magenta traces indicates the phase transition from the cubic to orthorhombic phase, grey trace indicates the orthorhombic phase, dark green indicates disordered phases from the orthorhombic structure to the Fm-3m (high temperature) phase, purple represents the Fm-3m (high temperature) while the light green traces reveal the transition to the $\mathrm{Fe}_{1.30} \mathrm{Co}_{1.70} \mathrm{C}$ phase and black is the $\mathrm{Fe}_{0.97} \mathrm{Co}_{1.03}$. Bolded black traces represent the patterns that were Rietveld refined. 13

Supporting Figure 9: Rietveld refinement of the OAm passivated PBA samples at a) $30^{\circ} \mathrm{C}$, b) $181^{\circ} \mathrm{C}$, c) $234^{\circ} \mathrm{C}$, d) $252{ }^{\circ} \mathrm{C}$, e) $449^{\circ} \mathrm{C}$. Samples were collected on the advanced light source operating at $25 \mathrm{KeV}$................................................................................................. 14

Supporting Figure 10: Size dependent powder diffraction patterns for a) the $\mathrm{K}\left[\mathrm{Fe}_{2-\mathrm{x}} \mathrm{Co}_{\mathrm{x}}(\mathrm{CN})_{6}\right]$ b) the $\mathrm{Fe}_{3-\mathrm{x}} \mathrm{Co}_{\mathrm{x}} \mathrm{C}$, and c) $\mathrm{Fe}_{2-\mathrm{x}} \mathrm{Co}_{\mathrm{x}}$ nanoparticles. The color of the trace indicate the material grown from the starting precursor, $129 \mathrm{~nm} \mathrm{~K}\left[\mathrm{Fe}_{2-\mathrm{x}} \mathrm{Co}_{\mathrm{x}}(\mathrm{CN})_{6}\right]$ (blue), $252 \mathrm{~nm} \mathrm{~K}\left[\mathrm{Fe}_{2-\mathrm{x}} \mathrm{Co}_{\mathrm{x}}(\mathrm{CN})_{6}\right]$ (black), 
$271 \mathrm{~nm} \mathrm{~K}\left[\mathrm{Fe}_{2-\mathrm{x}} \mathrm{Co}_{\mathrm{x}}(\mathrm{CN})_{6}\right](\mathrm{red}), 341 \mathrm{~nm} \mathrm{~K}\left[\mathrm{Fe}_{2-\mathrm{x}} \mathrm{Co}_{\mathrm{x}}(\mathrm{CN})_{6}\right]$ (grey), and $408 \mathrm{~nm} \mathrm{~K}\left[\mathrm{Fe}_{2-\mathrm{x}} \mathrm{Co}_{\mathrm{x}}(\mathrm{CN})_{6}\right]$ (green). 16

Supporting Figure 11: Elemental ratios determined by ICP-MS displaying percent iron in each sample. The blue traces indicate the $\mathrm{KCo}_{x}\left[\mathrm{Fe}_{2-\mathrm{x}}(\mathrm{CN})_{6}\right]$, grey indicate $\mathrm{Fe}_{3-\mathrm{x}} \mathrm{Co}_{\mathrm{x}} \mathrm{C}$, and red indicate $\mathrm{Fe}_{2-\mathrm{x}} \mathrm{Co}_{\mathrm{x}}$ 17

Supporting Figure 12: pXRD of a) PBA and b) $\mathrm{Fe}_{3-\mathrm{x}} \mathrm{Co}_{\mathrm{x}} \mathrm{C}$ from PBA synthesis reactions containing 1.5:1, 5:1, 7:1, and 9:1, Fe:Co metal salts. C) ICP-MS data of the isolated PBAs and $\mathrm{Fe}_{3-\mathrm{x}} \mathrm{Co}_{\mathrm{x}} \mathrm{C}$. 18

Supporting Figure 13: Calculated lattice constant, c, for the $\mathrm{Fe}_{3-\mathrm{x}} \mathrm{Co}_{\mathrm{x}} \mathrm{C}$ where open symbols show the size dependent data whereas the shaded symbols illustrate the elemental compositioncontrolled samples. The observed shift of lattice constant implies alloying of the nanocarbides. 19 Supporting Figure 14: a) SEM image of the $\left.129 \mathrm{~nm} \mathrm{KCo} \times \mathrm{Fe}_{2-\mathrm{x}}(\mathrm{CN}) 6\right]$, b) low-resolution TEM image of the $\mathrm{Fe}_{3-\mathrm{x}} \mathrm{Co}_{\mathrm{x}} \mathrm{C}$ from the $129 \mathrm{~nm} \mathrm{PBA}, \mathrm{c}$ ) selected TEM image of the $\mathrm{Fe}_{2-\mathrm{x}} \mathrm{Co}_{\mathrm{x}}$ from the $129 \mathrm{~nm}$ PBA, d) high-resolution TEM image of $\mathrm{Fe}_{3-\mathrm{x}} \mathrm{Co}_{\mathrm{x}} \mathrm{C}$, e) selected high-resolution TEM image of the $\mathrm{Fe}_{2-\mathrm{x}} \mathrm{Co}_{\mathrm{x}}$. Histograms and Gaussian fits for the f) $\left.\mathrm{KCo}_{x}\left[\mathrm{Fe}_{2-\mathrm{x}}(\mathrm{CN}) 6\right], \mathrm{g}\right) \mathrm{Fe}_{3-\mathrm{x}} \mathrm{Co}_{\mathrm{x}} \mathrm{C}$, and $\mathrm{h}$ ) $\mathrm{Fe}_{2-\mathrm{x}} \mathrm{Co}_{\mathrm{x}}$. 20

Supporting Figure 15: a) SEM image of the $252 \mathrm{~nm} \mathrm{KCo} x\left[\mathrm{Fe}_{2-\mathrm{x}}(\mathrm{CN}) 6\right]$, b) low-resolution TEM image of the $\mathrm{Fe}_{3-\mathrm{x}} \mathrm{Co}_{\mathrm{x}} \mathrm{C}$ from the $252 \mathrm{~nm} \mathrm{PBA}, \mathrm{c}$ ) selected TEM image of the $\mathrm{Fe}_{2-\mathrm{x}} \mathrm{Co}_{\mathrm{x}}$ from the $252 \mathrm{~nm}$ PBA, d) high-resolution TEM image of $\mathrm{Fe}_{3-\mathrm{x}} \mathrm{Co}_{\mathrm{x}} \mathrm{C}$, e) selected high-resolution TEM image of the $\mathrm{Fe}_{2-\mathrm{x}} \mathrm{Co}_{\mathrm{x}}$. Histograms and Gaussian fits for the f) $\left.\mathrm{KCo}_{x}\left[\mathrm{Fe}_{2-\mathrm{x}}(\mathrm{CN}) 6\right], \mathrm{g}\right) \mathrm{Fe}_{3-\mathrm{x}} \mathrm{Co}_{\mathrm{x}} \mathrm{C}$, and $\mathrm{h}$ ) $\mathrm{Fe}_{2-\mathrm{x}} \mathrm{Co}_{\mathrm{x}}$. 21

Supporting Figure 16: a) Selected SEM image of the $271 \mathrm{~nm} \mathrm{KCo}_{1.09}\left[\mathrm{Fe}_{0.91}(\mathrm{CN})_{6}\right]$, selected lowresolution TEM image of the b) $\mathrm{Fe}_{1.30} \mathrm{Co}_{1.70} \mathrm{C}$ and c) $\mathrm{Fe}_{0.97} \mathrm{Co}_{1.03}$. High-resolution TEM image of d) $\mathrm{Fe}_{1.30} \mathrm{Co}_{1.70} \mathrm{C}$, and e) $\mathrm{Fe}_{0.97} \mathrm{Co}_{1.03}$. Histograms and Gaussian fits for the f) $\mathrm{KCo}_{1.09}\left[\mathrm{Fe}_{0.91}(\mathrm{CN})_{6}\right]$,

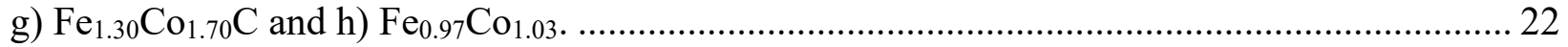
Supporting Figure 17: a) SEM image of the $341 \mathrm{~nm} \mathrm{KCo} x\left[\mathrm{Fe}_{2-\mathrm{x}}(\mathrm{CN}) 6\right]$, b) low-resolution TEM image of the $\mathrm{Fe}_{3-\mathrm{x}} \mathrm{Co}_{\mathrm{x}} \mathrm{C}$ from the $341 \mathrm{~nm} \mathrm{PBA}$, c) selected TEM image of the $\mathrm{Fe}_{2-\mathrm{x}} \mathrm{Co}_{\mathrm{x}}$ from the $341 \mathrm{~nm}$ PBA, d) high-resolution TEM image of $\mathrm{Fe}_{3-\mathrm{x}} \mathrm{Co}_{\mathrm{x}} \mathrm{C}$, e) selected high-resolution TEM image of the $\mathrm{Fe}_{2-x} \mathrm{Co}_{x}$. Histograms and Gaussian fits for the f) $\left.\mathrm{KCo}_{x}\left[\mathrm{Fe}_{2-\mathrm{x}}(\mathrm{CN}) 6\right], \mathrm{g}\right) \mathrm{Fe}_{3-\mathrm{x}} \mathrm{Co}_{\mathrm{x}} \mathrm{C}$, and $\mathrm{h}$ ) $\mathrm{Fe}_{2-\mathrm{x}} \mathrm{Co}_{\mathrm{x}}$. 23

Supporting Figure 18: a) SEM image of the $408 \mathrm{~nm} \mathrm{KCo}{ }_{x}\left[\mathrm{Fe}_{2-\mathrm{x}}(\mathrm{CN}) 6\right]$, b) low-resolution TEM image of the $\mathrm{Fe}_{3-\mathrm{x}} \mathrm{Co}_{\mathrm{x}} \mathrm{C}$ from the $408 \mathrm{~nm} \mathrm{PBA}$, c) selected TEM image of the $\mathrm{Fe}_{2-\mathrm{x}} \mathrm{Co}_{\mathrm{x}}$ from the $408 \mathrm{~nm}$ PBA, d) high-resolution TEM image of $\mathrm{Fe}_{3-\mathrm{x}} \mathrm{Co}_{\mathrm{x}} \mathrm{C}$, e) selected high-resolution TEM image of the $\mathrm{Fe}_{2-x} \mathrm{Co}_{x}$. Histograms and Gaussian fits for the f) $\left.\mathrm{KCo}_{x}\left[\mathrm{Fe}_{2-\mathrm{x}}(\mathrm{CN}) 6\right], \mathrm{g}\right) \mathrm{Fe}_{3-\mathrm{x}} \mathrm{Co}_{\mathrm{x}} \mathrm{C}$, and $\mathrm{h}$ ) $\mathrm{Fe}_{2-\mathrm{x}} \mathrm{Co}_{\mathrm{x}}$. 24

Supporting Figure 19: SEM images of reaction aliquots taken at $350{ }^{\circ} \mathrm{C}$ at a) $0 \mathrm{~min}$, b) $15 \mathrm{~min}$, c) $30 \mathrm{~min}$, and d) $60 \mathrm{~min}$. The scale bars for the main figures are $1,000 \mathrm{~nm}$ while the insets in

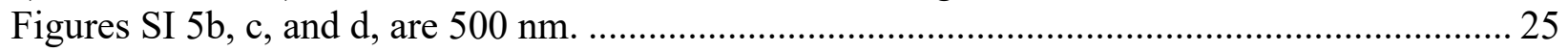

Supporting Figure 20: Characterization of a PBA heated to $180^{\circ} \mathrm{C}$ in OAm for $6 \mathrm{~h}$. a) FT-IR characterization of the M-CN stretch showing the weakened M-C bond at $2074 \mathrm{~cm}^{-1}$, evident in the orthorhombic structure. Bright field TEM image (b) and high resolution TEM image showing the FFT of the light and dark regions; both regions are assigned to the orthorhombic structure. e) Dark field TEM image of a PBA cube where the yellow line represents the EELS line scan and f) data from the EELS line scan where the color of the trace represents the area from the line scan. 
Supporting Figure 21: Reaction concentration vs. resultant nanoparticle size. Black triangle is the original collapse at $32 \mathrm{mM}$ and the blue squares are collapses at 3,64, and $161 \mathrm{mM}$. TEM images of a) $3 \mathrm{mM}$ collapse, b) $64 \mathrm{mM}$ collapse, and c) $161 \mathrm{mM}$ collapse and accompanying histograms in d) $3 \mathrm{mM}$, e) $64 \mathrm{mM}$, and f) $161 \mathrm{mM}$. Statistics were generated by analyzing >300 particles. 27

Supporting Figure 22: DSC-TGA measurements of a $129+22$ (red), $341+56$ (blue), and $408+$ $80 \mathrm{~nm}$ (black) $\mathrm{KCo}_{\mathrm{x}}\left[\mathrm{Fe}_{2-\mathrm{x}}(\mathrm{CN})_{6}\right]$ Prussian blue analogues. The samples were heated under $\mathrm{Ar}$ at $10{ }^{\circ} \mathrm{C} / \mathrm{min}$. 28

Supporting Table 1: Parameters refined during Rietveld analysis of data taken during dynamic ALS measurements of the $\mathrm{H}_{2} \mathrm{O}$ passivated samples. 8

Supporting Table 2: Parameters refined during Rietveld analysis of data taken during dynamic ALS measurements of the OAm passivated samples. 15 

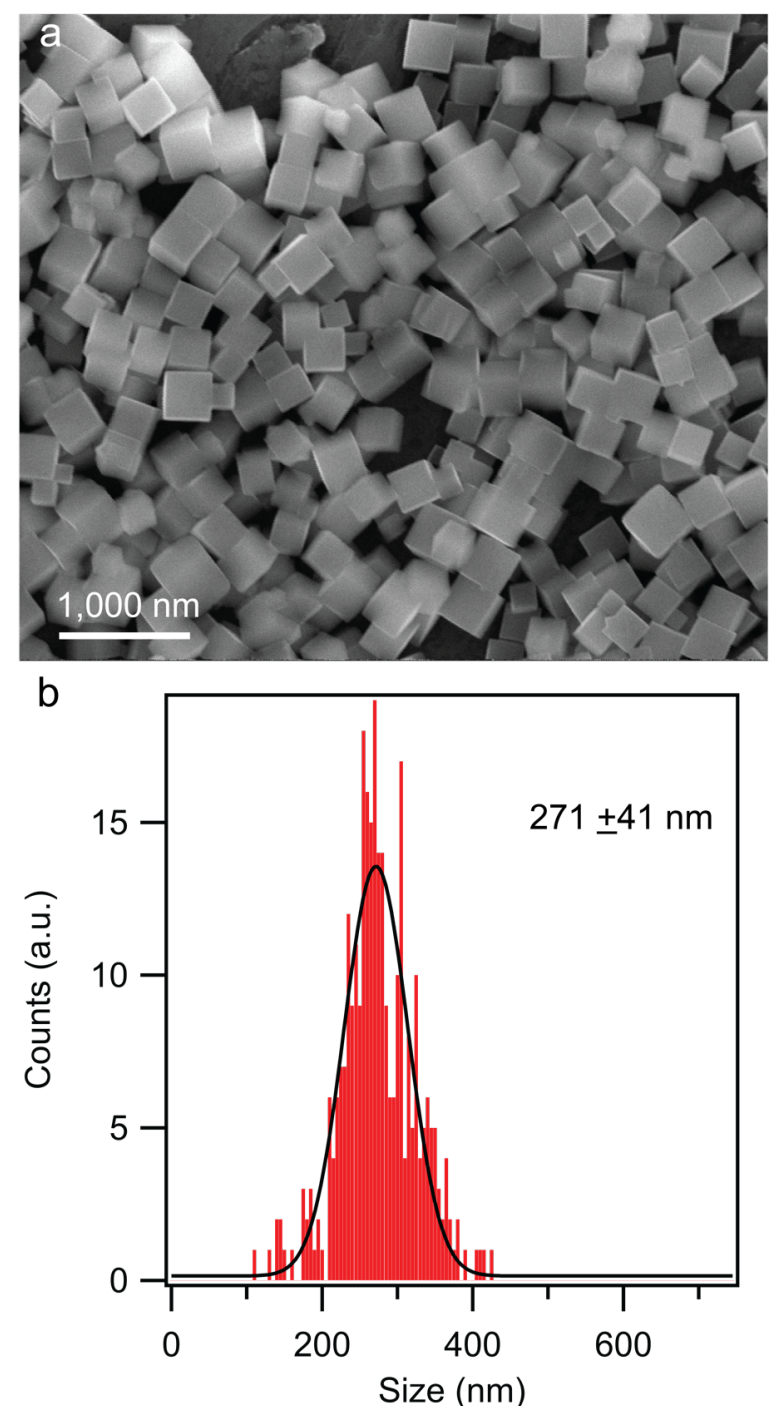

Supporting Figure 1: a) SEM image of 271 $\pm 41 \mathrm{~nm} \mathrm{KCo}_{1.09}\left[\mathrm{Fe}_{0.91}(\mathrm{CN})_{6}\right]$ and b) Gaussian distribution generated by measuring the cube length for $>300$ PBAs. 


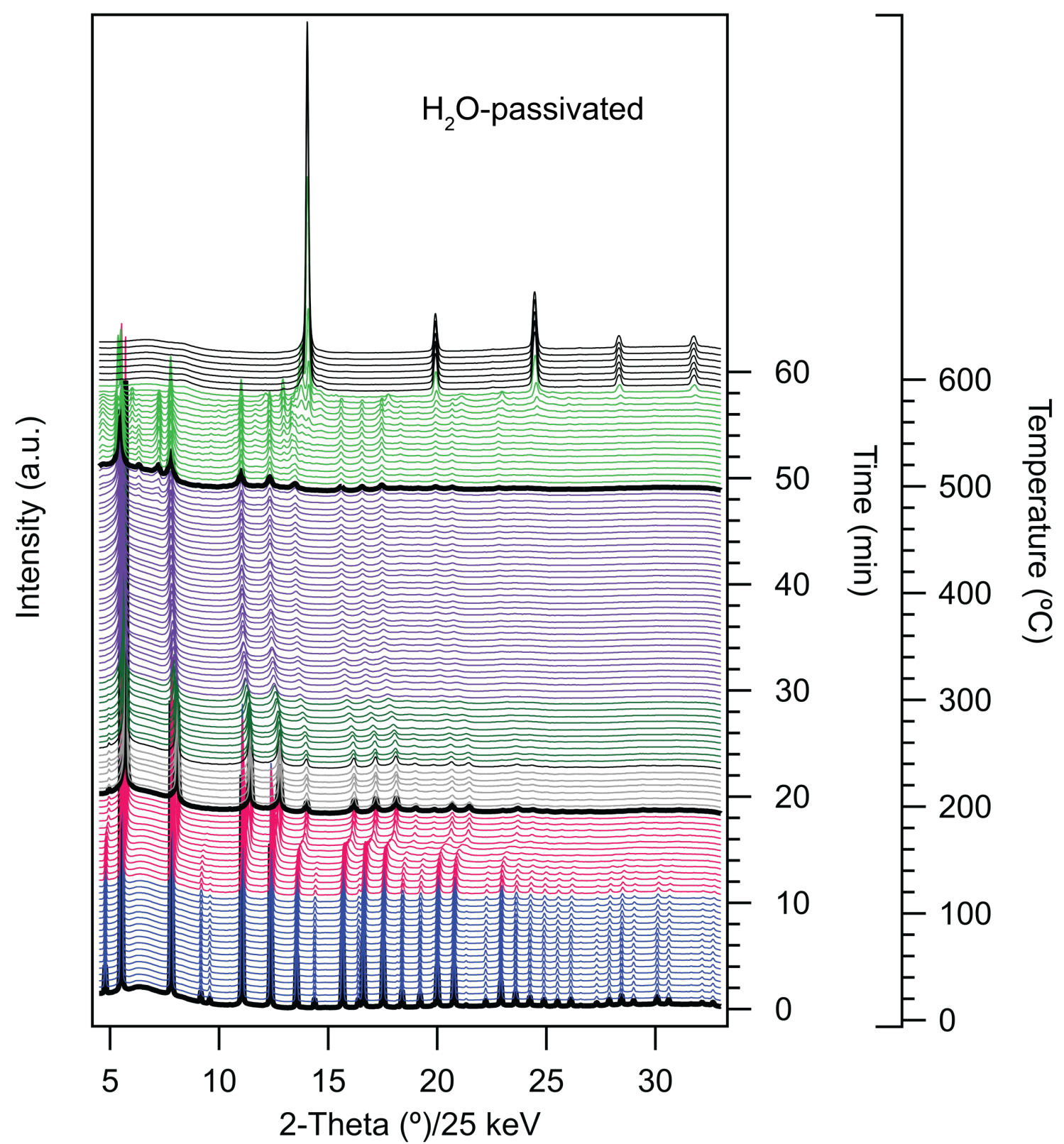

Supporting Figure 2: In-situ high-temperature powder x-ray diffraction patterns from the advanced light source operating at $25 \mathrm{keV}$ of the $\mathrm{H}_{2} \mathrm{O}$ passivated $\mathrm{KCo}_{1.09}\left[\mathrm{Fe}_{0.91}(\mathrm{CN})_{6}\right]$ sample. The heating ramp is $10{ }^{\circ} \mathrm{C} / \mathrm{min}$ from $18{ }^{\circ} \mathrm{C}$ to $600{ }^{\circ} \mathrm{C}$. Data was collected every 34 seconds during the heating ramp. Nitrogen was flowing at a rate of $15 \mathrm{~mL} / \mathrm{min}$ to eliminate oxidization. The blue is the $\mathrm{KCo}_{1.09}\left[\mathrm{Fe}_{0.91}(\mathrm{CN})_{6}\right]$, the magenta traces indicates the phase transition from the cubic to orthorhombic phase, grey trace indicates the orthorhombic phase, dark green indicates disordered phases from the orthorhombic structure to the $F m-3 m$ (high temperature) phase, purple represents the $F m-3 m$ (high temperature) while the light green traces reveal the transition to the $\mathrm{Fe}_{1.30} \mathrm{Co}_{1.70} \mathrm{C}$ phase and black is the $\mathrm{Fe}_{0.97} \mathrm{Co}_{1.03}$. Bolded black traces represent the patterns that were Rietveld refined. 

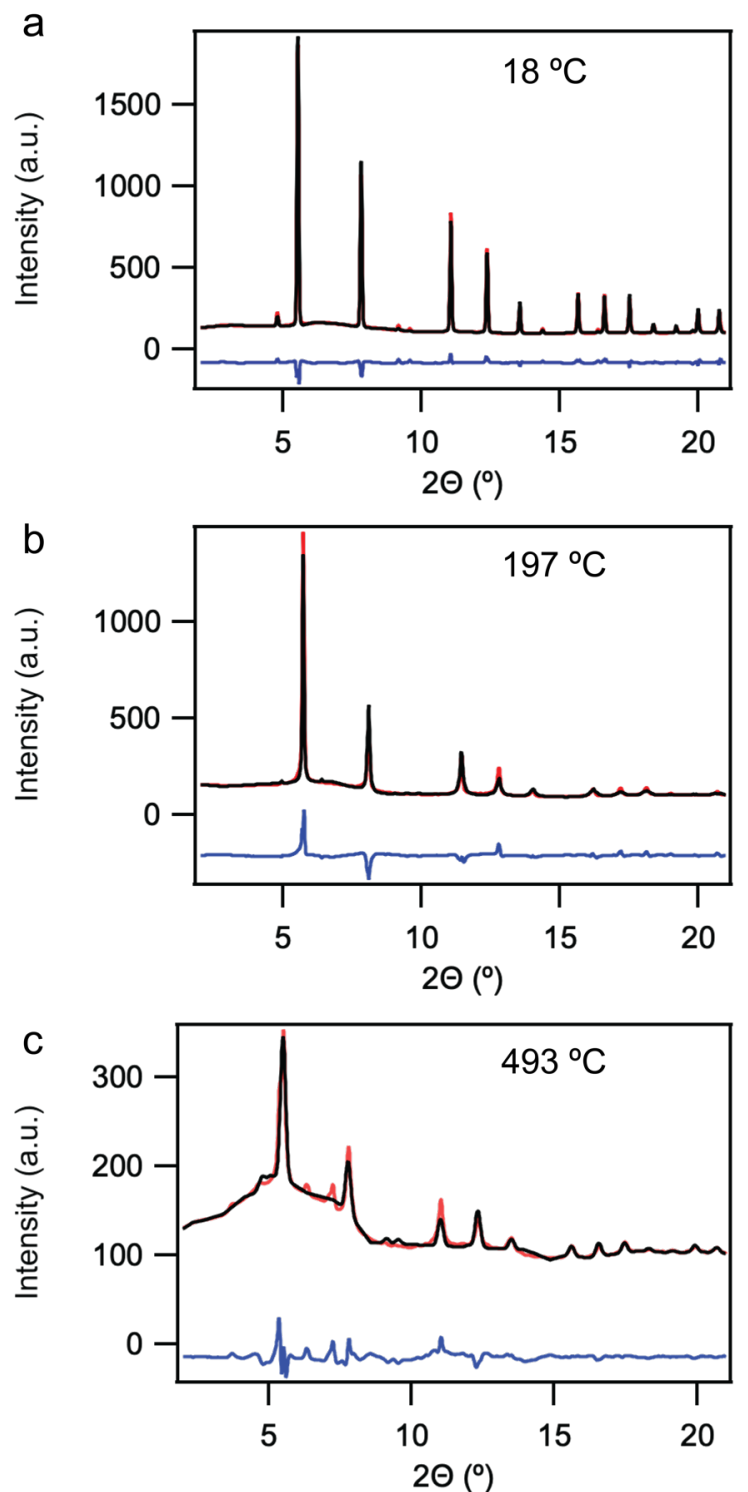

Supporting Figure 3: Rietveld refinement on ALS patterns taken at a) $18^{\circ} \mathrm{C}$, b) $197^{\circ} \mathrm{C}$, and c) $493{ }^{\circ} \mathrm{C}$. 
Supporting Table 1: Parameters refined during Rietveld analysis of data taken during dynamic ALS measurements of the $\mathrm{H}_{2} \mathrm{O}$ passivated samples.

\begin{tabular}{|c|c|c|c|c|}
\hline \multicolumn{5}{|c|}{$\mathrm{H}_{2} \mathrm{O}$ Passivated PBA, Refined Parameters } \\
\hline Temperature $\left({ }^{\circ} \mathrm{C}\right)$ & $a(\AA)$ & $b(\AA)$ & $c(\AA)$ & Phase \\
\hline 18 & 10.31654 & 10.31654 & 10.31654 & $F m-3 m(\mathrm{LT})$ \\
\hline 197 & 9.93331 & 6.98925 & 7.06601 & $P m n 2_{1}$ \\
\hline 493 & 10.35486 & 10.35486 & 10.35486 & $F m-3 m(\mathrm{HT})$ \\
\hline
\end{tabular}




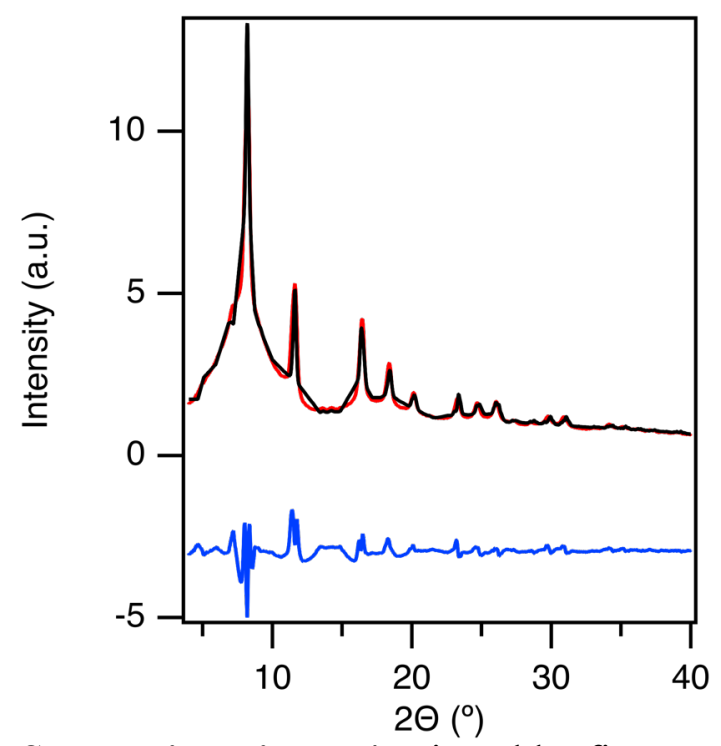

Supporting Figure 4: Rietveld refinement of the sample held $197{ }^{\circ} \mathrm{C}$ for $1 \mathrm{hr}$. The sample was run using a Mo $\mathrm{K}_{\alpha}$ anode to reduce the $\mathrm{Fe}$ and Co fluorescence. 


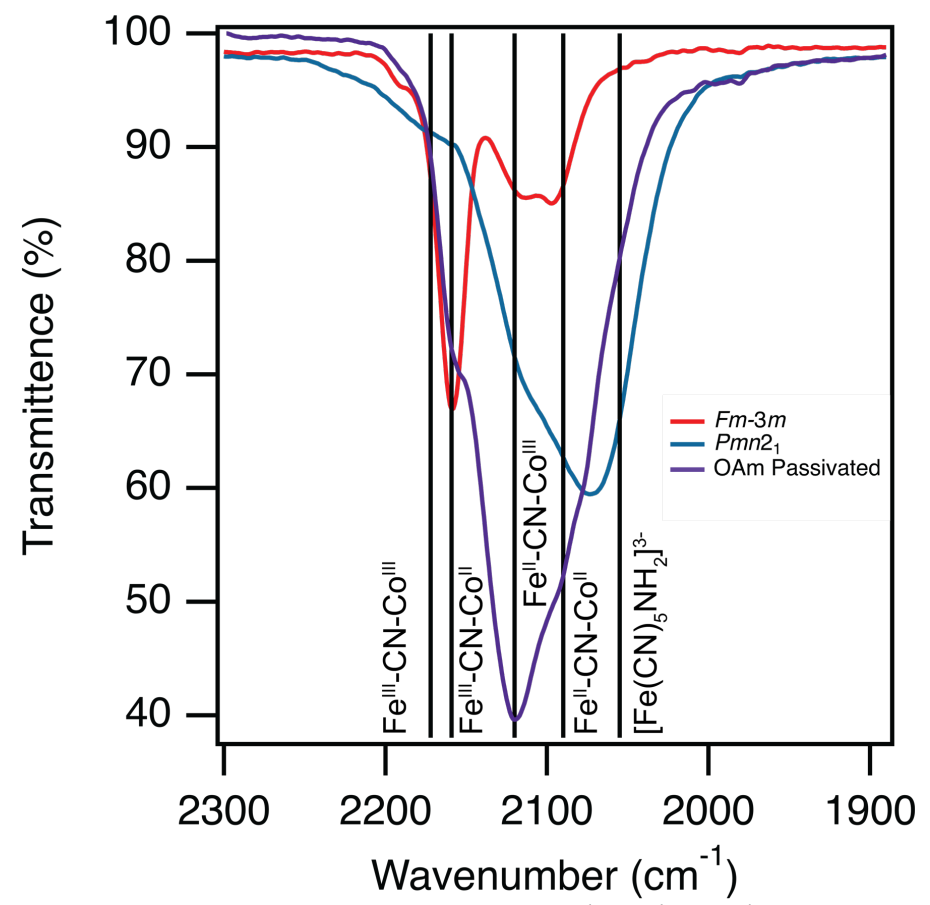

Supporting Figure 5: FT-IR showing the M-CN stretch of the $F m-3 m$ (cubic) phase (red trace), OAm passivated $F m-3 m$ (cubic) PBAs (purple trace), and $P m n 2_{1}$ orthorhombic phase (blue trace). 


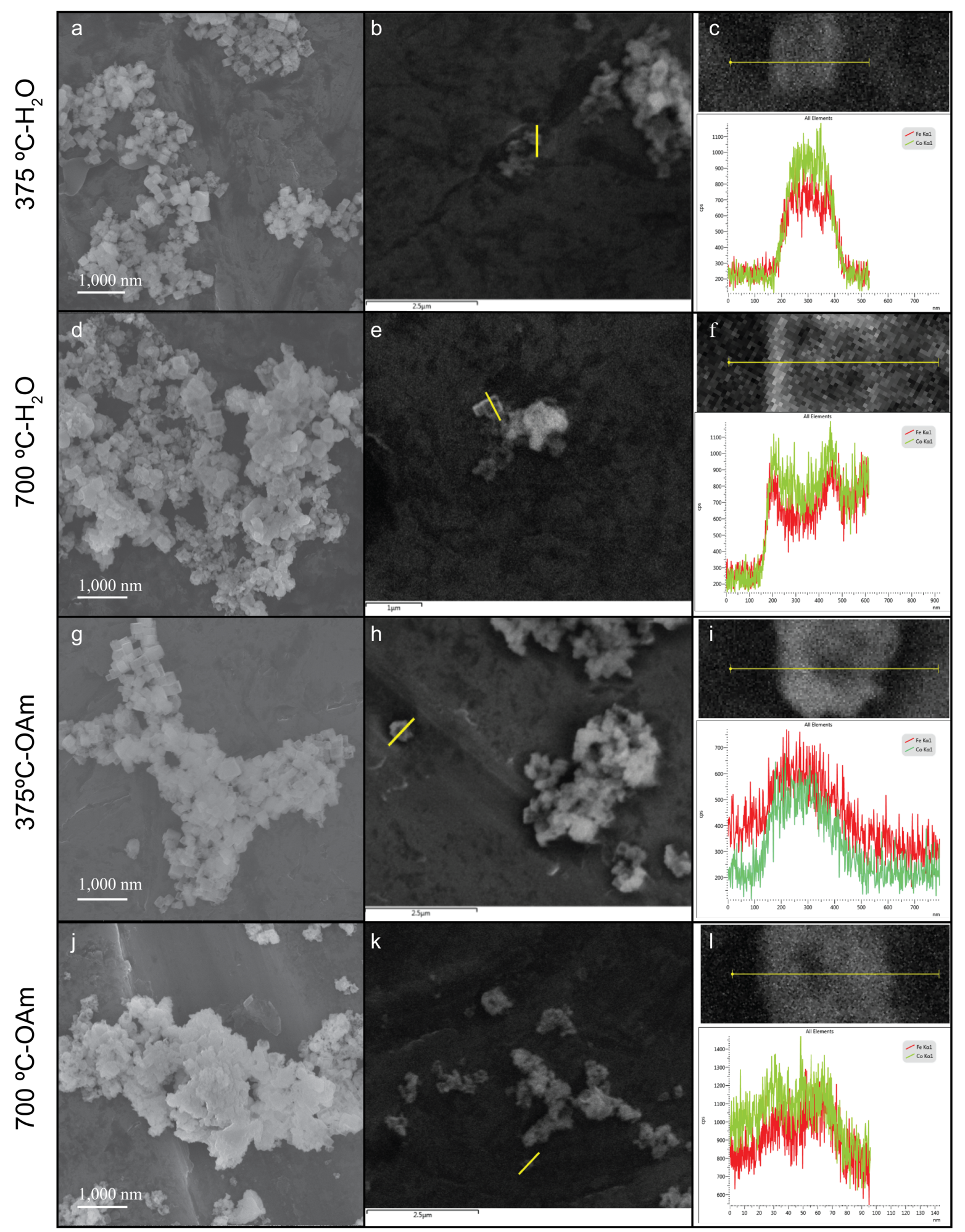

Supporting Figure 6: SEM images of an $\mathrm{H}_{2} \mathrm{O}$ passivated $271 \pm 41 \mathrm{~nm} \mathrm{KCo}{ }_{1.09}\left[\mathrm{Fe}_{0.91}(\mathrm{CN})_{6}\right]$ held at $375^{\circ} \mathrm{C}$ for $1 \mathrm{hr}(\mathrm{a}-\mathrm{b})$ and $700{ }^{\circ} \mathrm{C}(\mathrm{d}-\mathrm{e})$. EDX line scans of the material showing the $\mathrm{Fe}$ and Co signals are displayed in $\mathrm{c}$ and $\mathrm{f}$. TEM images of an OAm passivated $271 \pm 41 \mathrm{~nm}$ $\mathrm{KCo}_{1.09}\left[\mathrm{Fe}_{0.91}(\mathrm{CN})_{6}\right]$ held at $375{ }^{\circ} \mathrm{C}$ for $1 \mathrm{hr}(\mathrm{g}-\mathrm{h})$ and $700{ }^{\circ} \mathrm{C}(\mathrm{j}-\mathrm{k})$. EDX line scans of the material showing the $\mathrm{Fe}$ and $\mathrm{Co}$ signals are displayed in $\mathrm{i}$ and $\mathrm{l}$. 


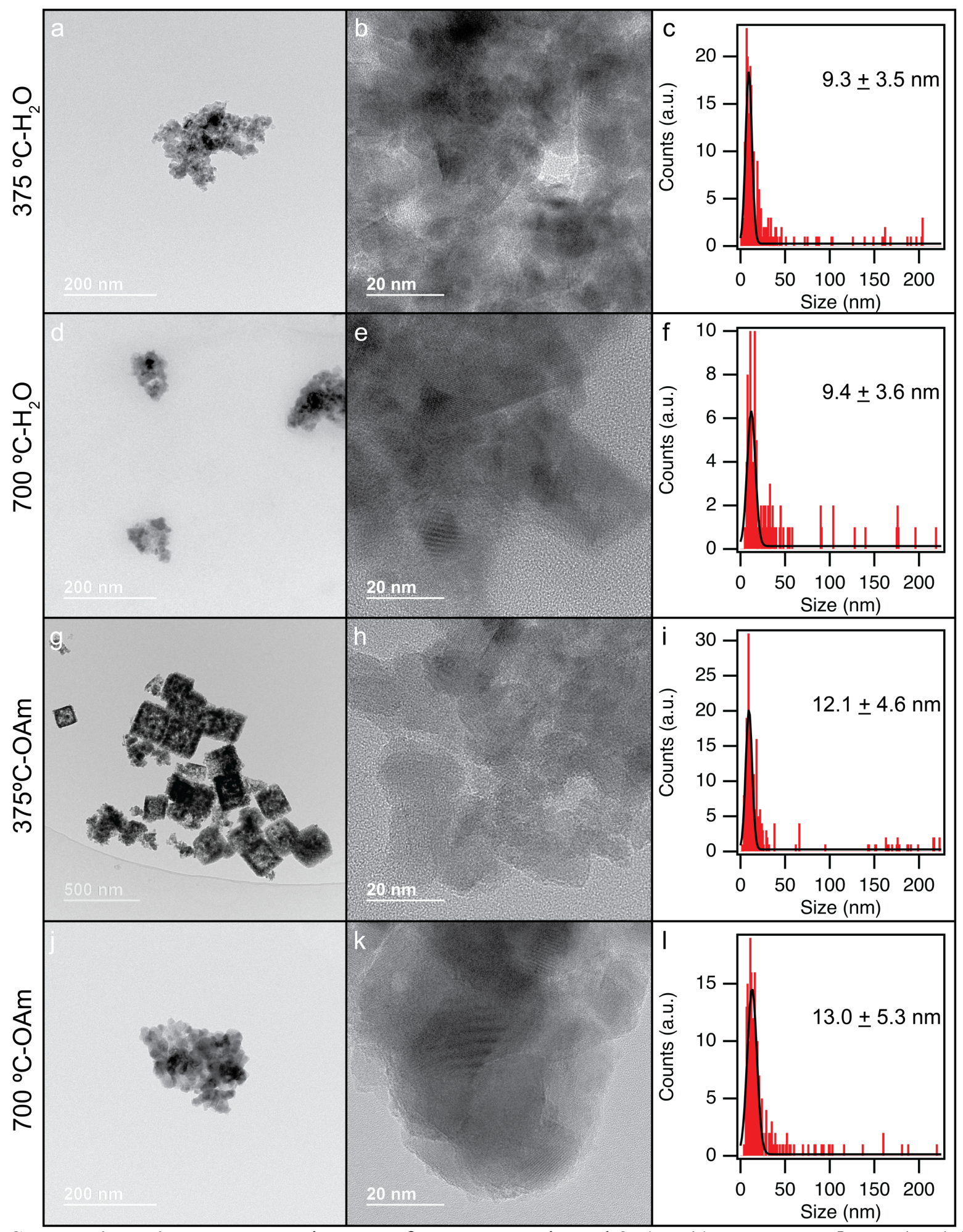

Supporting Figure 7: TEM images of an $\mathrm{H}_{2} \mathrm{O}$ passivated $271 \pm 41 \mathrm{~nm} \mathrm{KCo}{ }_{1.09}\left[\mathrm{Fe}_{0.91}(\mathrm{CN})_{6}\right]$ held at $375{ }^{\circ} \mathrm{C}$ for $1 \mathrm{hr}(\mathrm{a}-\mathrm{b})$ and $700{ }^{\circ} \mathrm{C}(\mathrm{d}-\mathrm{e})$. Distributions of the small material are displayed in $\mathrm{c}$ and $\mathrm{f}$. TEM images of an OAm passivated $271 \pm 41 \mathrm{~nm} \mathrm{KCo}_{1.09}\left[\mathrm{Fe}_{0.91}(\mathrm{CN})_{6}\right]$ held at 375 ${ }^{\circ} \mathrm{C}$ for $1 \mathrm{hr}(\mathrm{g}-\mathrm{h})$ and $700{ }^{\circ} \mathrm{C}(\mathrm{j}-\mathrm{k})$. Distributions of the small material are displayed in $\mathrm{i}$ and 1. 


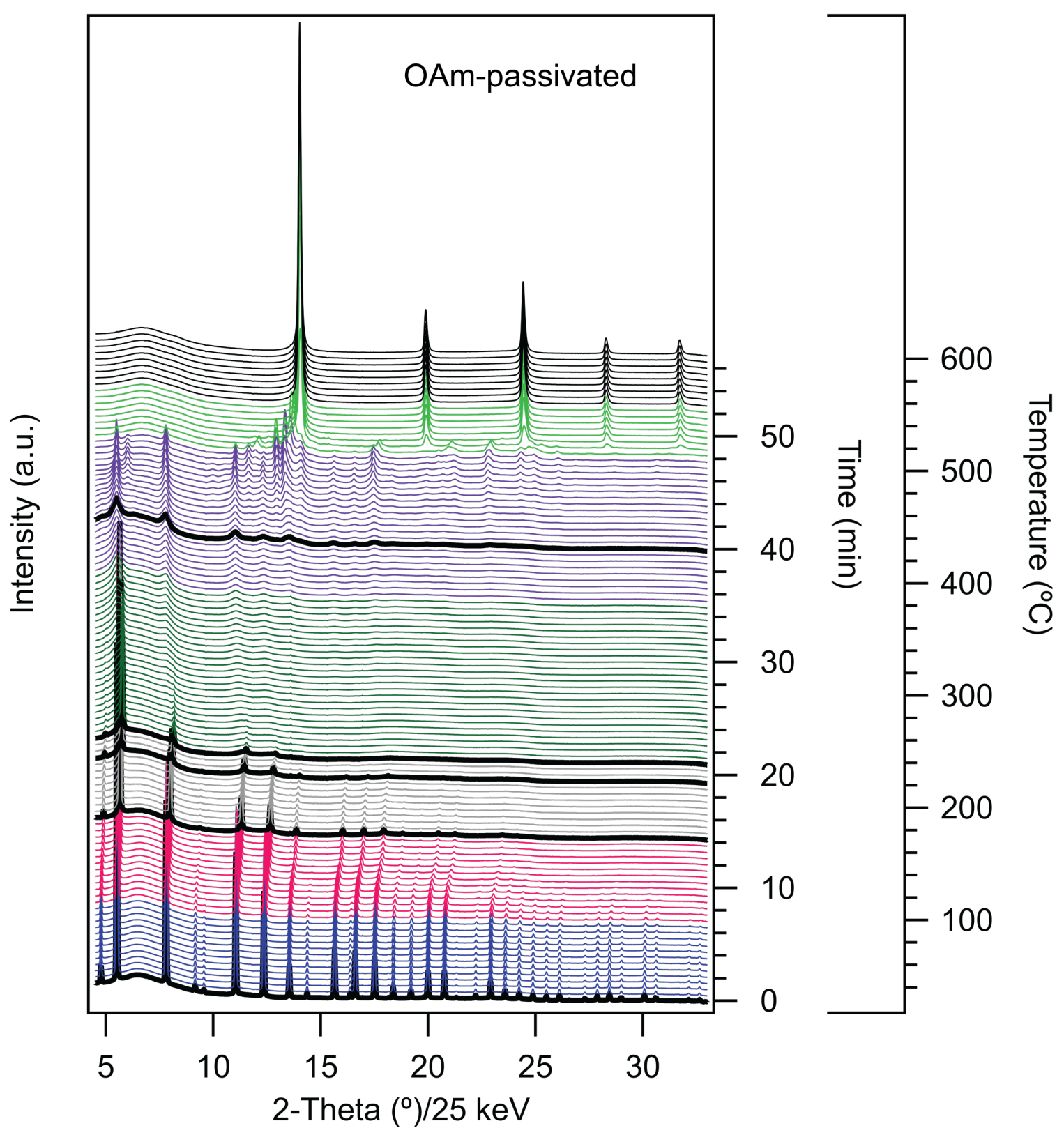

Supporting Figure 8: In-situ high-temperature powder x-ray diffraction patterns from the advanced light source operating at $25 \mathrm{keV}$ of the $\mathrm{OAm}$ passivated $\mathrm{KCo}_{1.09}\left[\mathrm{Fe}_{0.91}(\mathrm{CN})_{6}\right]$ sample. The heating ramp is $10{ }^{\circ} \mathrm{C} / \mathrm{min}$ from $30{ }^{\circ} \mathrm{C}$ to $600{ }^{\circ} \mathrm{C}$. Data was collected every 34 seconds during the heating ramp. Nitrogen was flowing at a rate of $15 \mathrm{~mL} / \mathrm{min}$ to eliminate oxidization. The blue is the $\mathrm{KCo}_{1.09}\left[\mathrm{Fe}_{0.91}(\mathrm{CN})_{6}\right]$, the magenta traces indicates the phase transition from the cubic to orthorhombic phase, grey trace indicates the orthorhombic phase, dark green indicates disordered phases from the orthorhombic structure to the $F m-3 m$ (high temperature) phase, purple represents the $F m-3 m$ (high temperature) while the light green traces reveal the transition to the $\mathrm{Fe}_{1.30} \mathrm{Co}_{1.70} \mathrm{C}$ phase and black is the $\mathrm{Fe}_{0.97} \mathrm{Co}_{1.03}$. Bolded black traces represent the patterns that were Rietveld refined. 

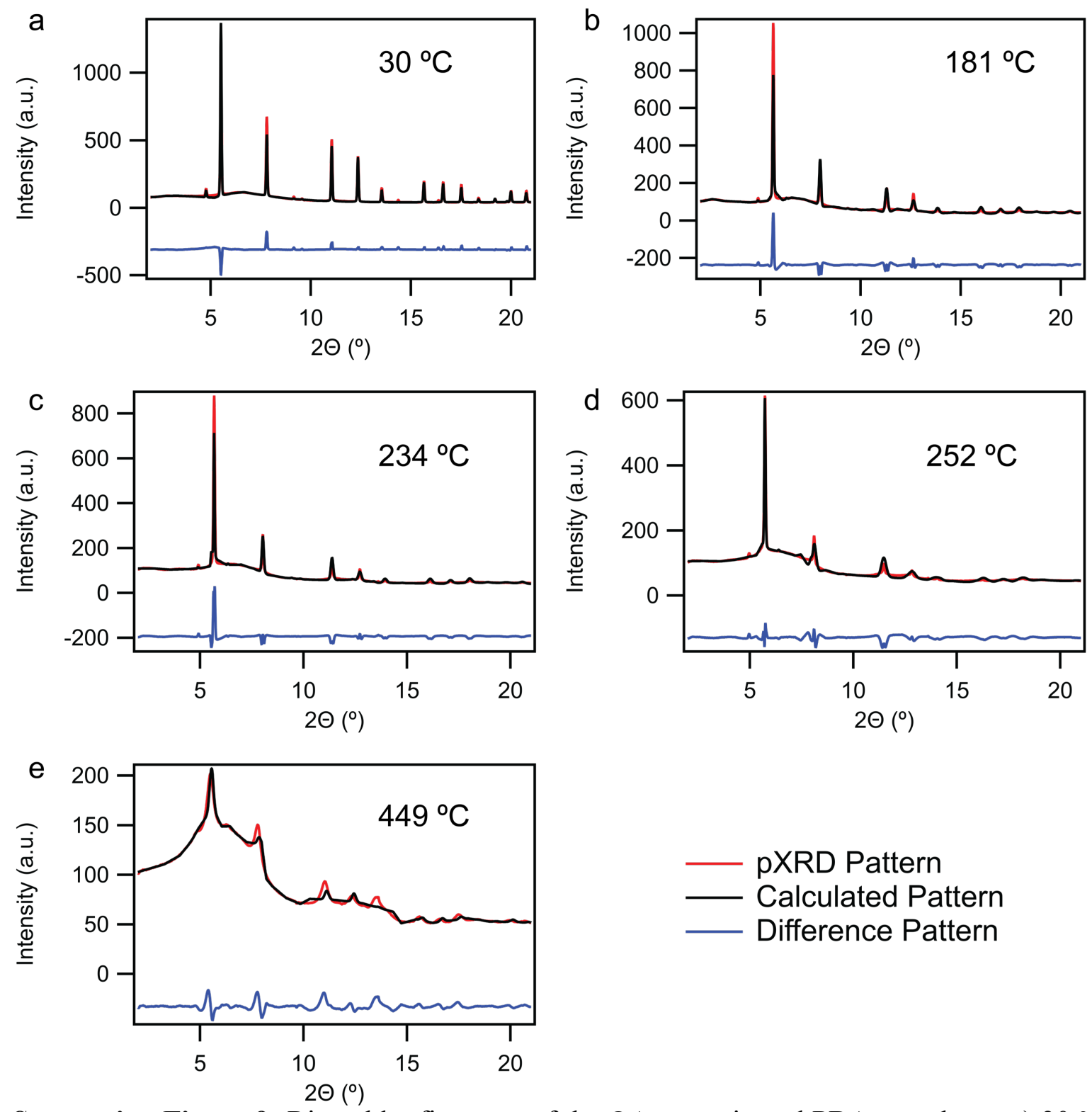

Supporting Figure 9: Rietveld refinement of the OAm passivated PBA samples at a) $30{ }^{\circ} \mathrm{C}$, b) $181{ }^{\circ} \mathrm{C}$, c) $234^{\circ} \mathrm{C}$, d) $252^{\circ} \mathrm{C}$, e) $449^{\circ} \mathrm{C}$. Samples were collected on the advanced light source operating at $25 \mathrm{KeV}$. 
Supporting Table 2: Parameters refined during Rietveld analysis of data taken during dynamic ALS measurements of the OAm passivated samples.

\begin{tabular}{|c|c|c|c|c|}
\hline \multicolumn{5}{|c|}{ OAm Passivated PBA, Refined Parameters } \\
\hline Temperature $\left({ }^{\circ} \mathrm{C}\right)$ & $a(\AA)$ & $b(\AA)$ & $c(\AA)$ & Phase \\
\hline 30 & 10.32142 & 10.32142 & 10.32142 & $F m-3 m(\mathrm{LT})$ \\
\hline 181 & 10.06405 & 7.119187 & 7.173005 & $P m n 2_{1}$ \\
\hline 234 & 10.02663 & 7.045343 & 7.125538 & $P m n 2_{1}$ \\
\hline 252 & 9.90216 & 6.935544 & 7.157715 & $P m n 2_{1}$ \\
\hline 449 & 10.25408 & 10.25408 & 10.25408 & $F m-3 m(\mathrm{HT})$ \\
\hline
\end{tabular}




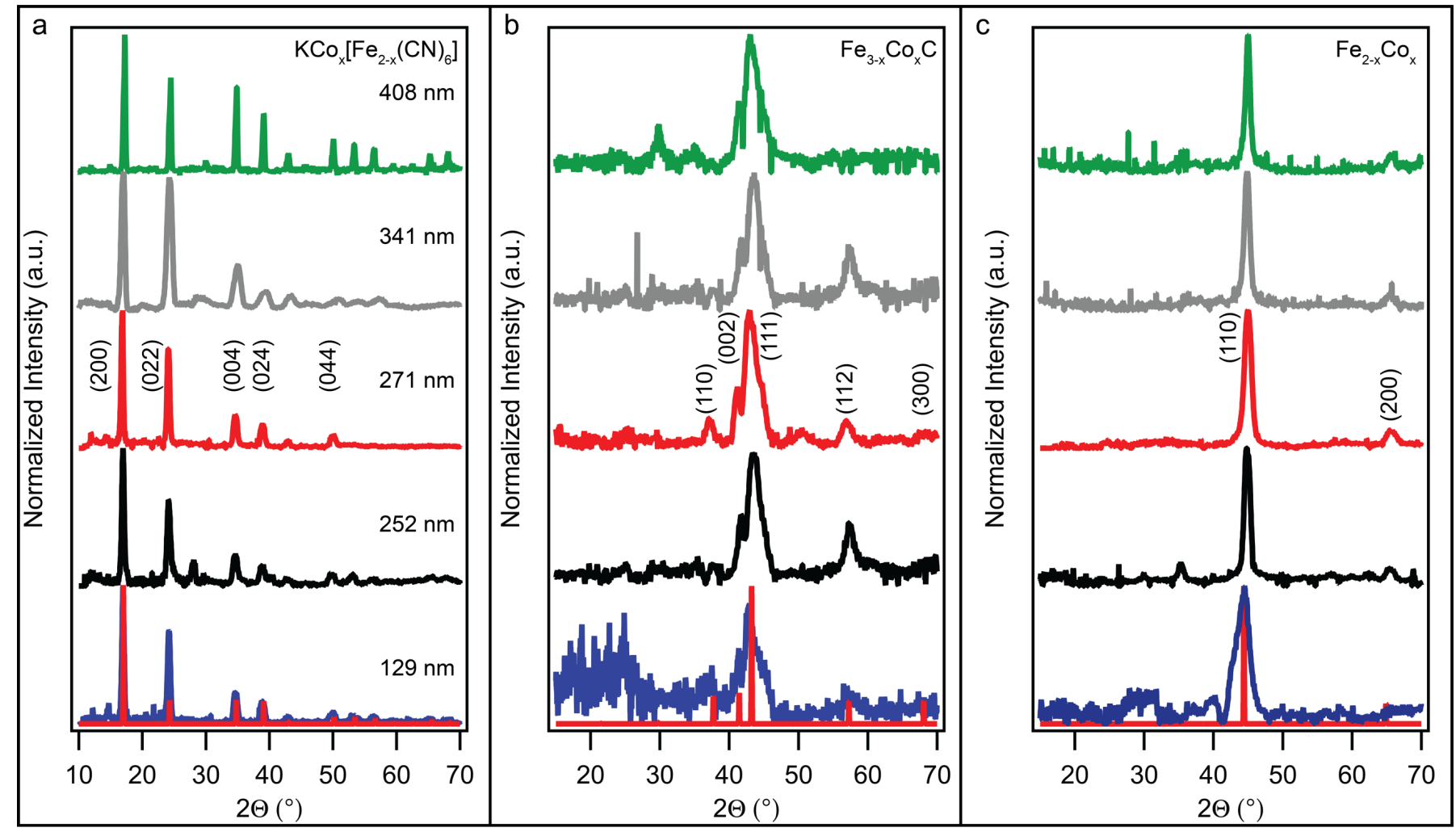

Supporting Figure 10: Size dependent powder diffraction patterns for a) the $\left.\mathrm{K}\left[\mathrm{Fe}_{2-\mathrm{x}} \mathrm{Co}_{\mathrm{x}}(\mathrm{CN})_{6}\right] \mathrm{b}\right)$ the $\mathrm{Fe}_{3-\mathrm{x}} \mathrm{Co}_{\mathrm{x}} \mathrm{C}$, and c) $\mathrm{Fe}_{2-\mathrm{x}} \mathrm{Co}_{\mathrm{x}}$ nanoparticles. The color of the trace indicate the material grown from the starting precursor, $129 \mathrm{~nm} \mathrm{~K}\left[\mathrm{Fe}_{2-\mathrm{x}} \mathrm{Co}_{\mathrm{x}}(\mathrm{CN})_{6}\right]$ (blue), $252 \mathrm{~nm} \mathrm{~K}\left[\mathrm{Fe}_{2-\mathrm{x}} \mathrm{Co}_{\mathrm{x}}(\mathrm{CN})_{6}\right]$ (black), $271 \mathrm{~nm} \mathrm{~K}\left[\mathrm{Fe}_{2-}\right.$ $\left.{ }_{x} \mathrm{Co}_{\mathrm{x}}(\mathrm{CN})_{6}\right]$ (red), $341 \mathrm{~nm} \mathrm{~K}\left[\mathrm{Fe}_{2-\mathrm{x}} \mathrm{Co}_{\mathrm{x}}(\mathrm{CN})_{6}\right]$ (grey), and $408 \mathrm{~nm} \mathrm{~K}\left[\mathrm{Fe}_{2-\mathrm{x}} \mathrm{Co}_{\mathrm{x}}(\mathrm{CN})_{6}\right]$ (green). 


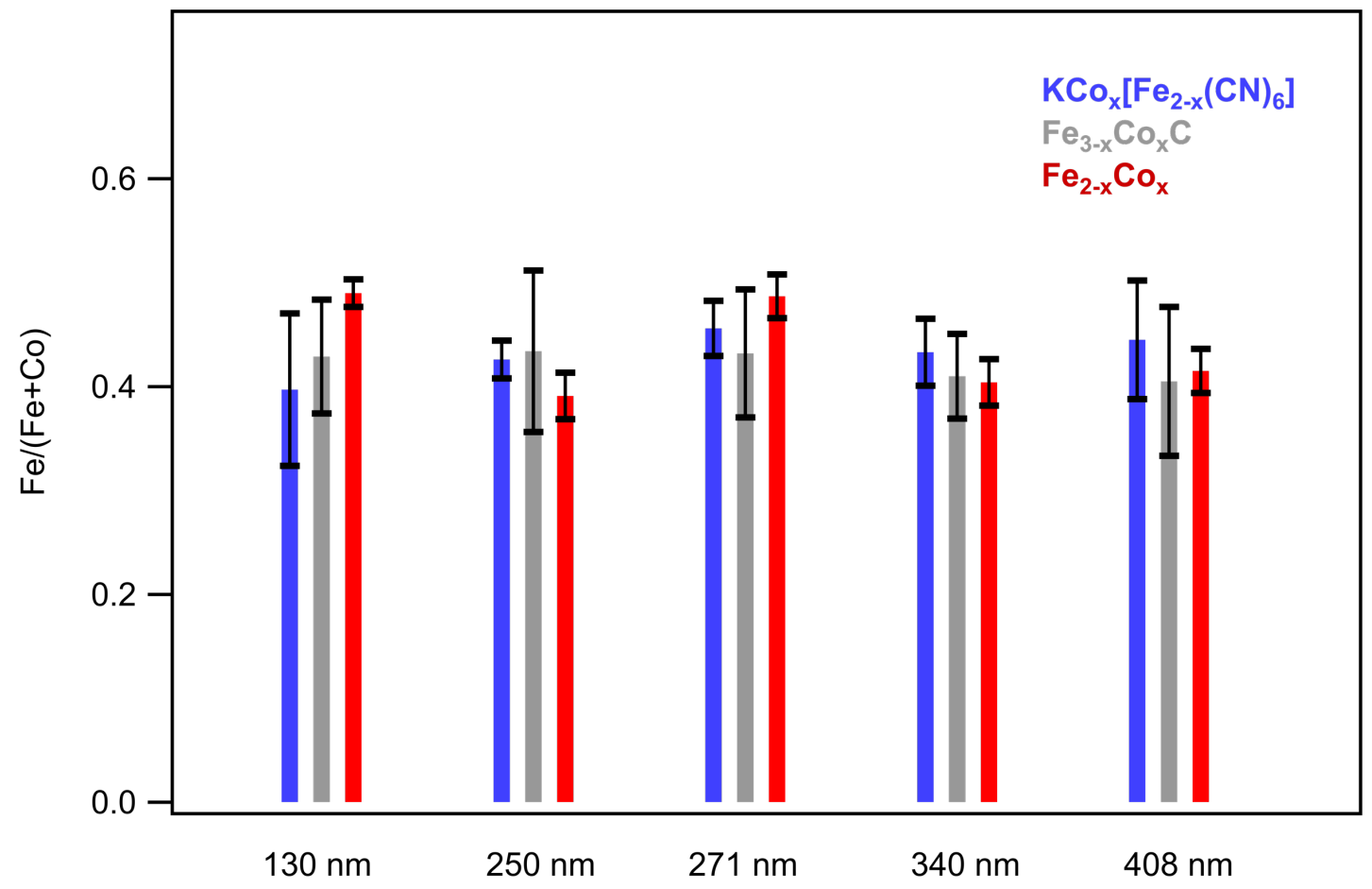

Supporting Figure 11: Elemental ratios determined by ICP-MS displaying percent iron in each sample. The blue traces indicate the $\mathrm{KCo}_{x}\left[\mathrm{Fe}_{2-\mathrm{x}}(\mathrm{CN})_{6}\right]$, grey indicate $\mathrm{Fe}_{3-\mathrm{x}} \mathrm{Co}_{\mathrm{x}} \mathrm{C}$, and red indicate $\mathrm{Fe}_{2-\mathrm{x}} \mathrm{Co}_{\mathrm{x}}$. 

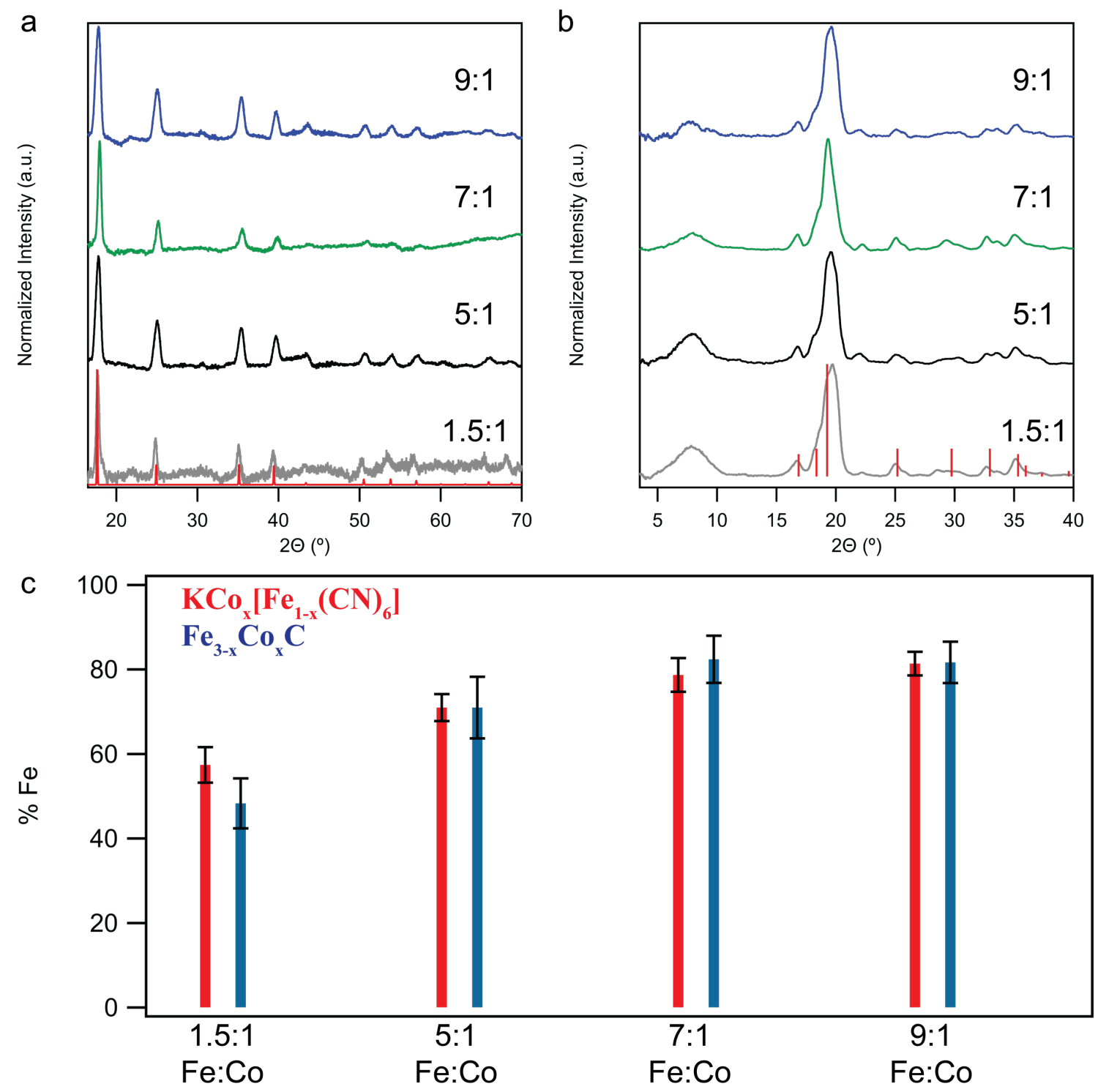

Supporting Figure 12: pXRD of a) PBA and b) $\mathrm{Fe}_{3-\mathrm{x}} \mathrm{Co}_{\mathrm{x}} \mathrm{C}$ from PBA synthesis reactions containing 1.5:1, 5:1, 7:1, and 9:1, Fe:Co metal salts. C) ICP-MS data of the isolated PBAs and $\mathrm{Fe}_{3-\mathrm{x}} \mathrm{Co}_{\mathrm{x}} \mathrm{C}$. 


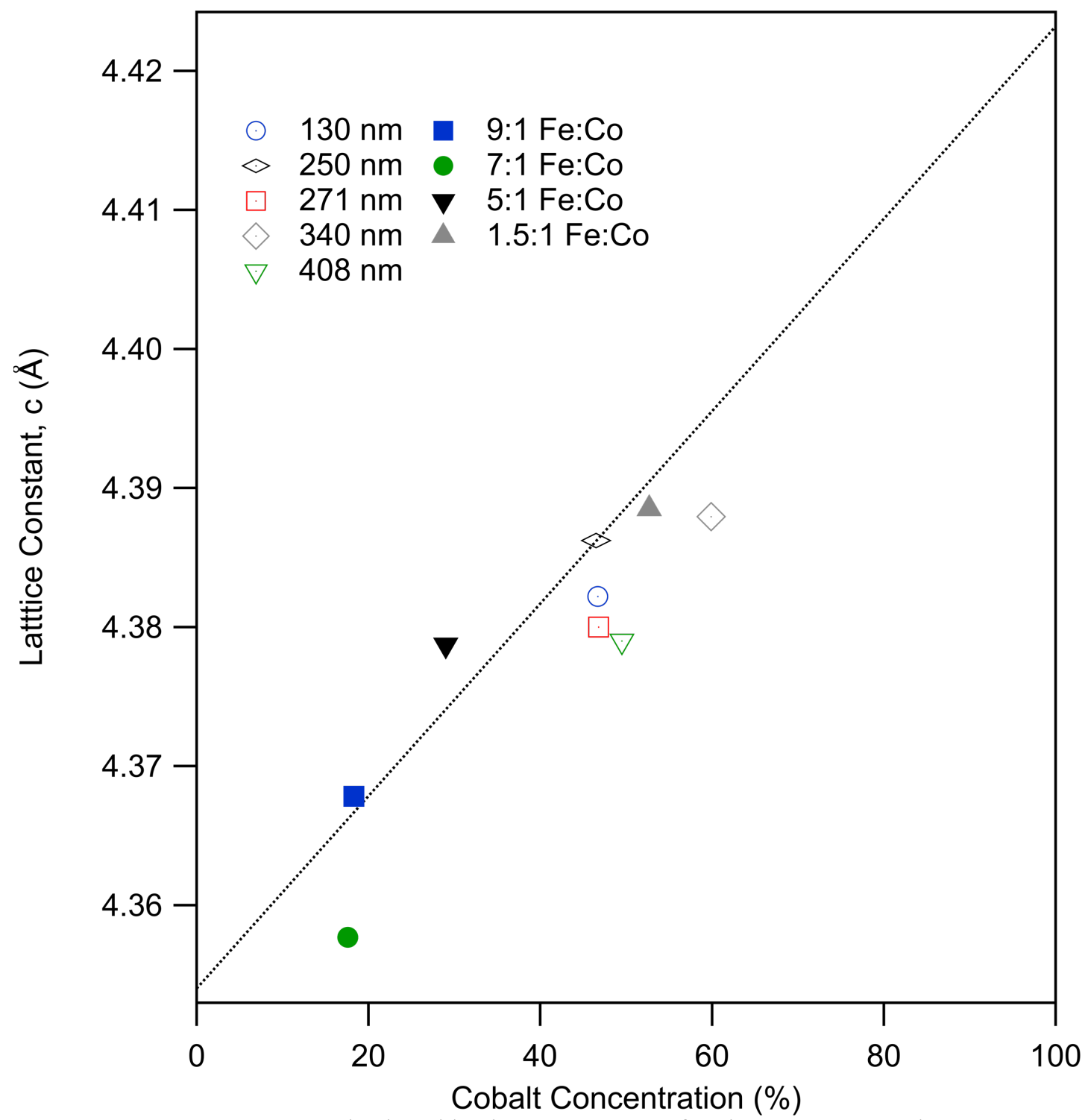

Supporting Figure 13: Calculated lattice constant, $\mathrm{c}$, for the $\mathrm{Fe}_{3-\mathrm{x}} \mathrm{Co}_{\mathrm{x}} \mathrm{C}$ where open symbols show the size dependent data whereas the shaded symbols illustrate the elemental composition-controlled samples. The observed shift of lattice constant implies alloying of the nanocarbides. 


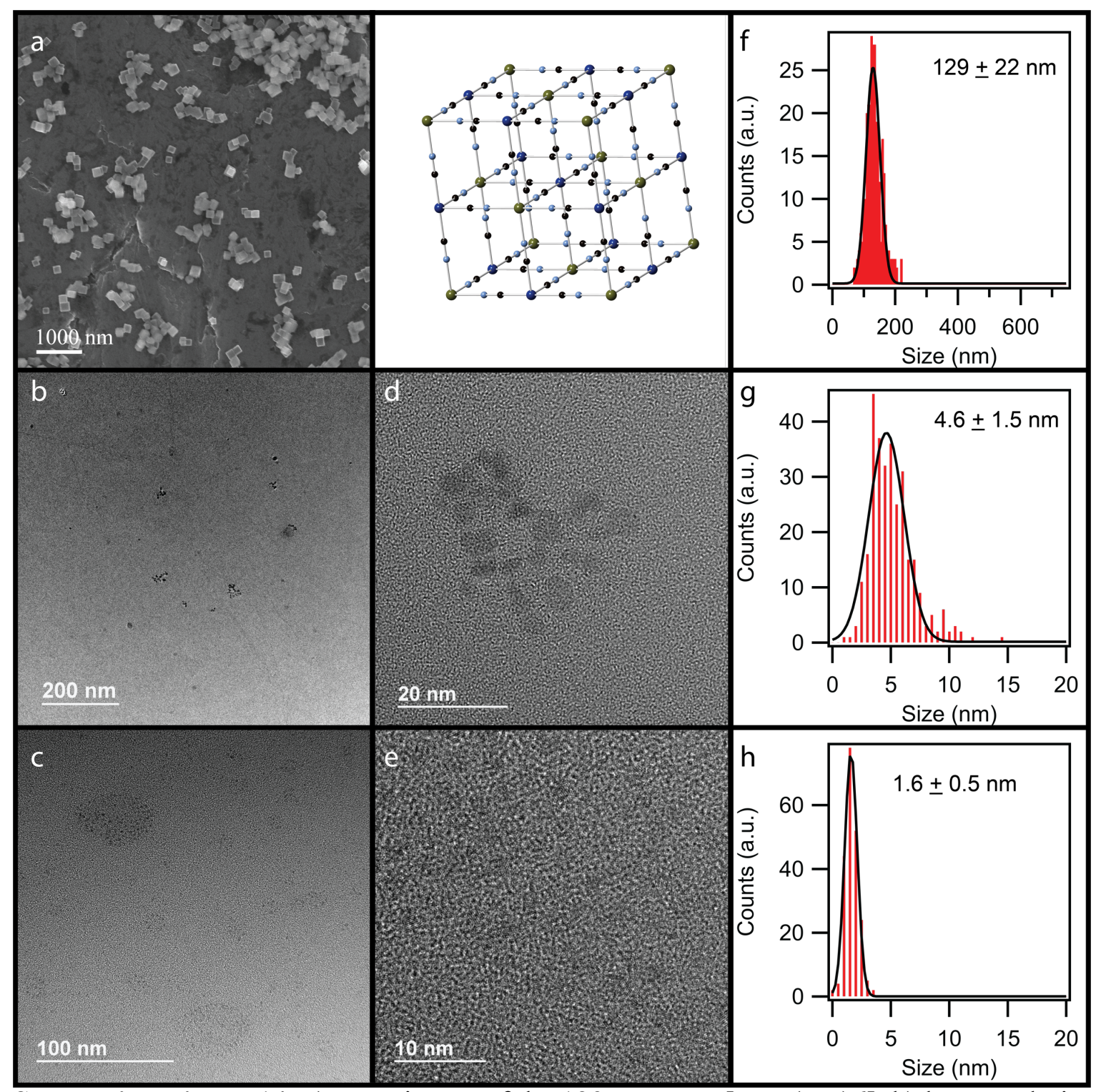

Supporting Figure 14: a) SEM image of the $129 \mathrm{~nm} \mathrm{KCo}$ [ $\left[\mathrm{Fe}_{2-\mathrm{x}}(\mathrm{CN}) 6\right]$, b) low-resolution TEM image of the $\mathrm{Fe}_{3-\mathrm{x}} \mathrm{Co}_{\mathrm{x}} \mathrm{C}$ from the $129 \mathrm{~nm}$ PBA, c) selected TEM image of the $\mathrm{Fe}_{2-\mathrm{x}} \mathrm{Co}_{\mathrm{x}}$ from the $129 \mathrm{~nm}$ PBA, d) high-resolution TEM image of $\mathrm{Fe}_{3-\mathrm{x}} \mathrm{Co}_{\mathrm{x}} \mathrm{C}$, e) selected highresolution TEM image of the $\mathrm{Fe}_{2-x} \mathrm{Co}_{x}$. Histograms and Gaussian fits for the f) $\mathrm{KCo}_{x}\left[\mathrm{Fe}_{2-}\right.$ $\left.\left.{ }_{x}(\mathrm{CN}) 6\right], \mathrm{g}\right) \mathrm{Fe}_{3-\mathrm{x}} \mathrm{Co}_{\mathrm{x}} \mathrm{C}$, and h) $\mathrm{Fe}_{2-\mathrm{x}} \mathrm{Co}_{\mathrm{x}}$. 


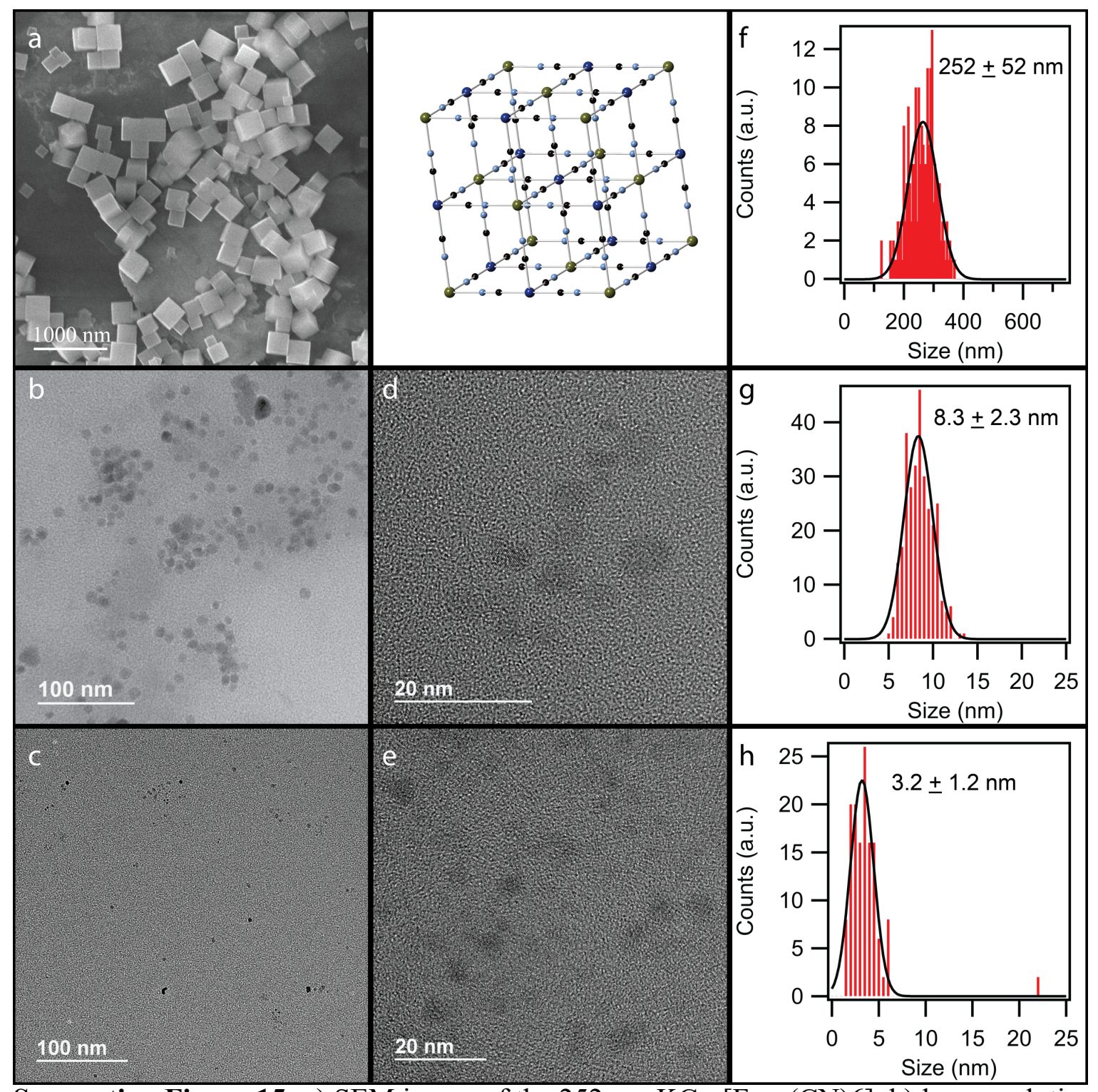

Supporting Figure 15: a) SEM image of the $252 \mathrm{~nm} \mathrm{KCo} x\left[\mathrm{Fe}_{2-\mathrm{x}}(\mathrm{CN}) 6\right]$, b) low-resolution TEM image of the $\mathrm{Fe}_{3-\mathrm{x}} \mathrm{Co}_{\mathrm{x}} \mathrm{C}$ from the $252 \mathrm{~nm}$ PBA, c) selected TEM image of the $\mathrm{Fe}_{2-\mathrm{x}} \mathrm{Co}_{\mathrm{x}}$ from the $252 \mathrm{~nm}$ PBA, d) high-resolution TEM image of $\mathrm{Fe}_{3-\mathrm{x}} \mathrm{Co}_{\mathrm{x}} \mathrm{C}$, e) selected highresolution TEM image of the $\mathrm{Fe}_{2-\mathrm{x}} \mathrm{Co}_{\mathrm{x}}$. Histograms and Gaussian fits for the f) $\mathrm{KCo}_{\mathrm{x}}\left[\mathrm{Fe}_{2-}\right.$ x(CN)6], g) $\mathrm{Fe}_{3-\mathrm{x}} \mathrm{Co}_{\mathrm{x}} \mathrm{C}$, and h) $\mathrm{Fe}_{2-\mathrm{x}} \mathrm{Co}_{\mathrm{x}}$. 


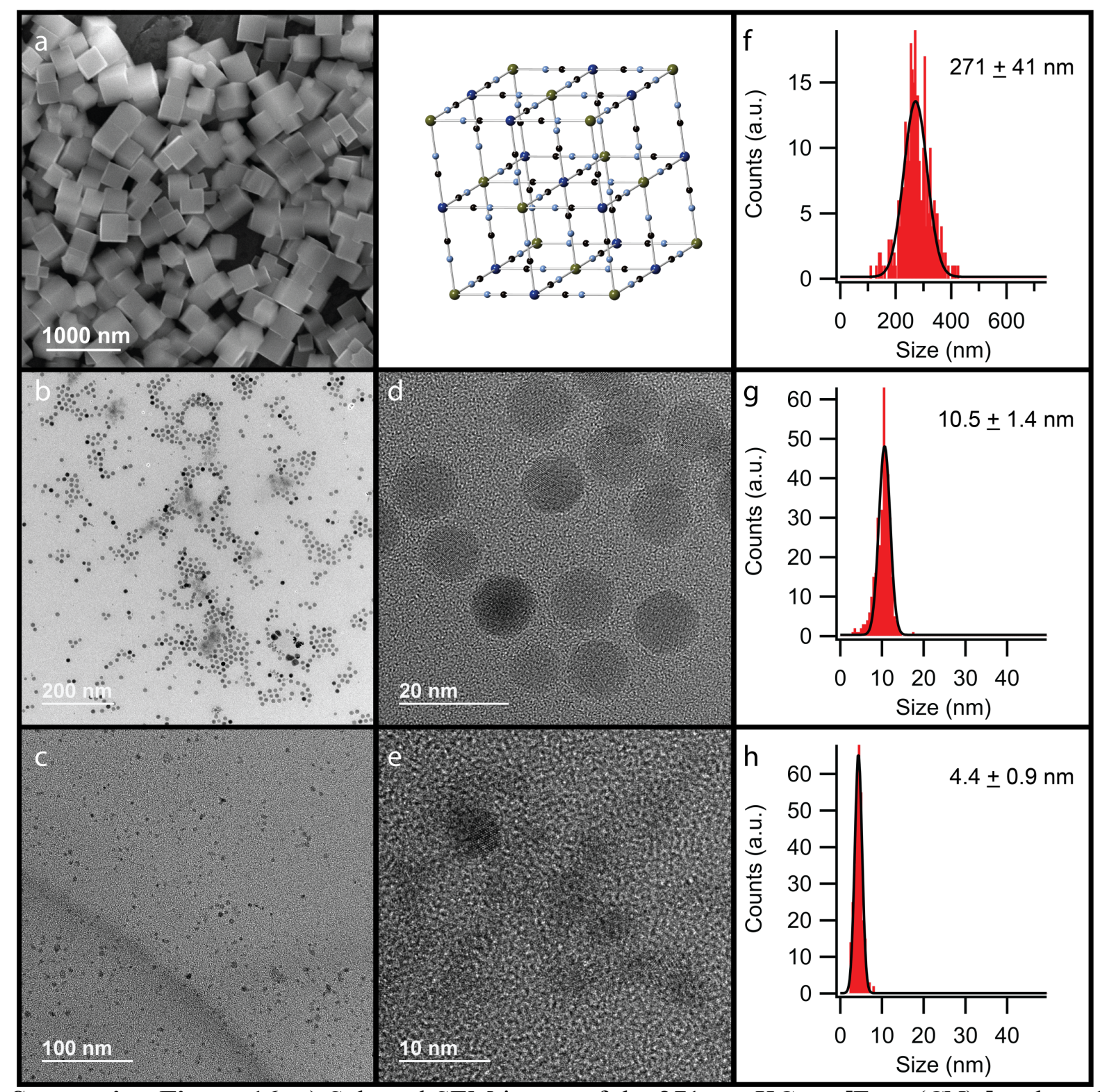

Supporting Figure 16: a) Selected SEM image of the $271 \mathrm{~nm} \mathrm{KCo} \mathrm{KC}_{1.09}\left[\mathrm{Fe}_{0.91}(\mathrm{CN})_{6}\right]$, selected low-resolution TEM image of the b) $\mathrm{Fe}_{1.30} \mathrm{Co}_{1.70} \mathrm{C}$ and c) $\mathrm{Fe}_{0.97} \mathrm{Co}_{1.03}$. High-resolution TEM image of d) $\mathrm{Fe}_{1.30} \mathrm{Co}_{1.70} \mathrm{C}$, and e) $\mathrm{Fe}_{0.97} \mathrm{Co}_{1.03}$. Histograms and Gaussian fits for the $\mathrm{f}$ ) $\mathrm{KCo}_{1.09}\left[\mathrm{Fe}_{0.91}(\mathrm{CN})_{6}\right]$, g) $\mathrm{Fe}_{1.30} \mathrm{Co}_{1.70} \mathrm{C}$ and h) $\mathrm{Fe}_{0.97} \mathrm{Co}_{1.03}$. 


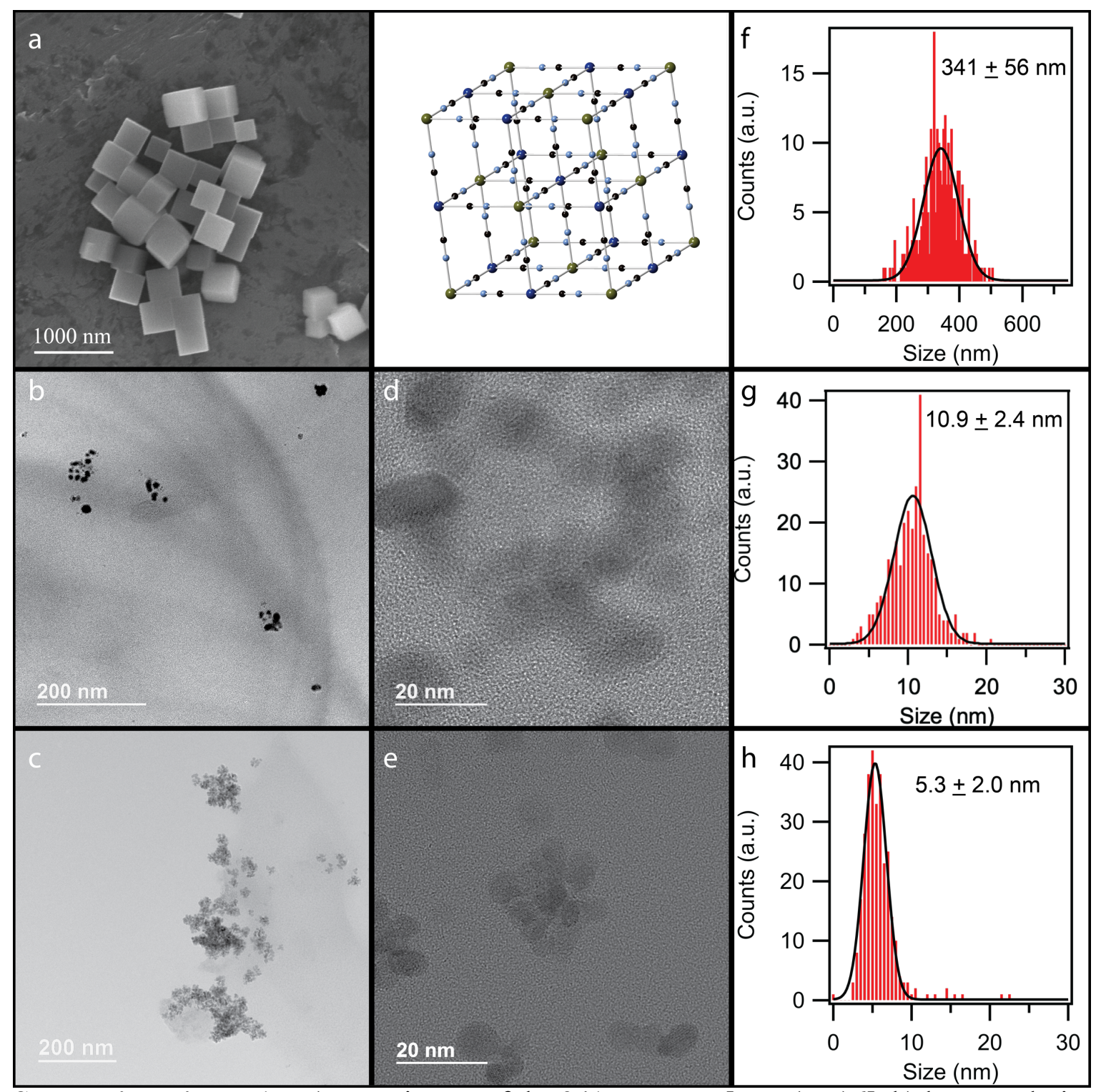

Supporting Figure 17: a) SEM image of the $341 \mathrm{~nm} \mathrm{KCo}$ [ $\left[\mathrm{Fe}_{2-\mathrm{x}}(\mathrm{CN}) 6\right]$, b) low-resolution TEM image of the $\mathrm{Fe}_{3-\mathrm{x}} \mathrm{Co}_{\mathrm{x}} \mathrm{C}$ from the $341 \mathrm{~nm}$ PBA, c) selected TEM image of the $\mathrm{Fe}_{2-\mathrm{x}} \mathrm{Co}_{\mathrm{x}}$ from the $341 \mathrm{~nm}$ PBA, d) high-resolution TEM image of $\mathrm{Fe}_{3-\mathrm{x}} \mathrm{Co}_{\mathrm{x}} \mathrm{C}$, e) selected highresolution TEM image of the $\mathrm{Fe}_{2-x} \mathrm{Co}_{x}$. Histograms and Gaussian fits for the f) $\mathrm{KCo}_{x}\left[\mathrm{Fe}_{2-}\right.$ $\left.\left.{ }_{x}(\mathrm{CN}) 6\right], \mathrm{g}\right) \mathrm{Fe}_{3-\mathrm{x}} \mathrm{Co}_{\mathrm{x}} \mathrm{C}$, and h) $\mathrm{Fe}_{2-\mathrm{x}} \mathrm{Co}_{\mathrm{x}}$. 


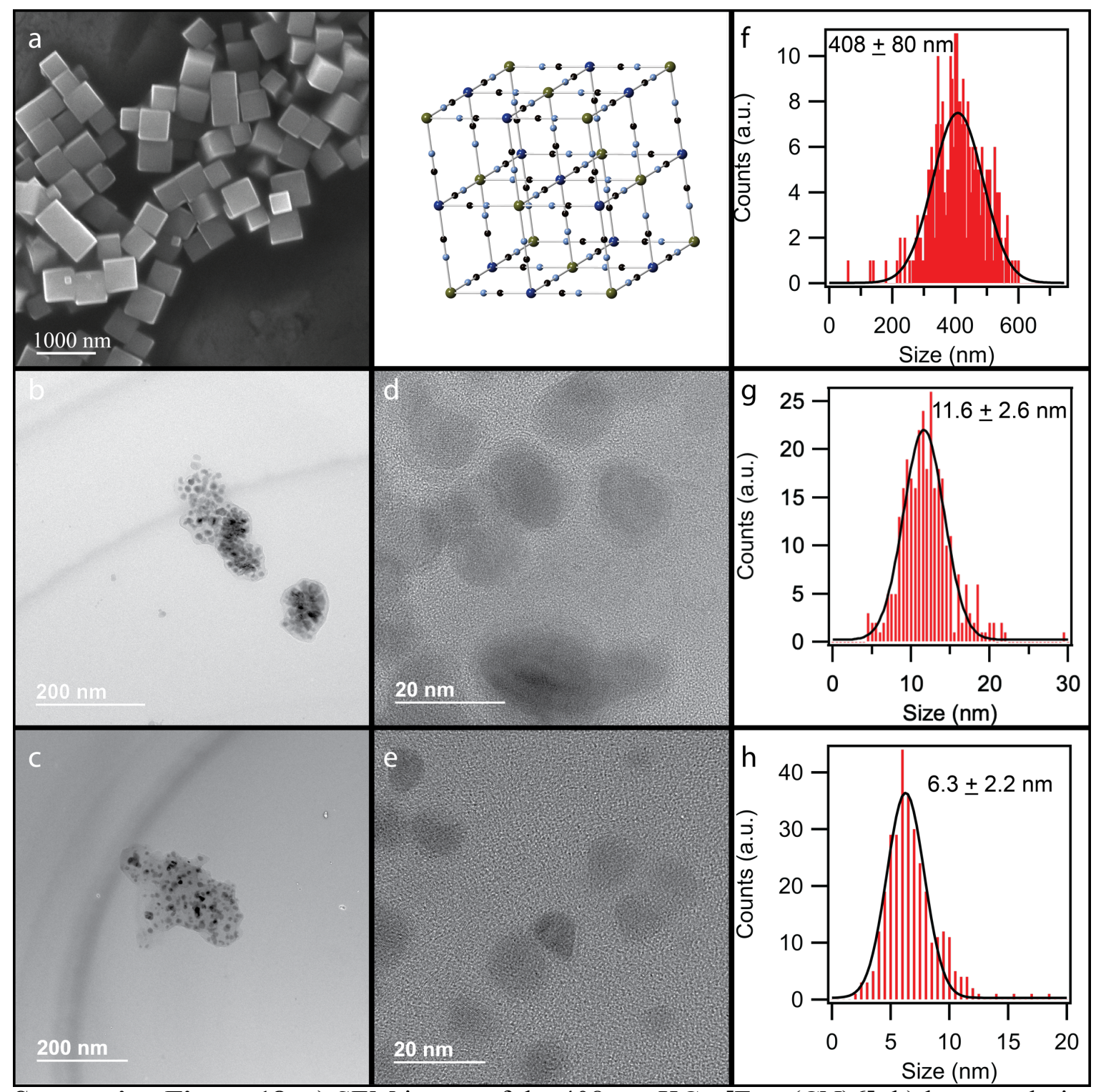

Supporting Figure 18: a) SEM image of the $408 \mathrm{~nm} \mathrm{KCo}$ [ $\left[\mathrm{Fe}_{2-\mathrm{x}}(\mathrm{CN}) 6\right]$, b) low-resolution TEM image of the $\mathrm{Fe}_{3-\mathrm{x}} \mathrm{Co}_{\mathrm{x}} \mathrm{C}$ from the $408 \mathrm{~nm}$ PBA, c) selected TEM image of the $\mathrm{Fe}_{2-\mathrm{x}} \mathrm{Co}_{\mathrm{x}}$ from the $408 \mathrm{~nm}$ PBA, d) high-resolution TEM image of $\mathrm{Fe}_{3-\mathrm{x}} \mathrm{Co}_{\mathrm{x}} \mathrm{C}$, e) selected highresolution TEM image of the $\mathrm{Fe}_{2-\mathrm{x}} \mathrm{Co}_{\mathrm{x}}$. Histograms and Gaussian fits for the f) $\mathrm{KCo}_{\mathrm{x}}\left[\mathrm{Fe}_{2-}\right.$ $x(\mathrm{CN}) 6], \mathrm{g}) \mathrm{Fe}_{3-\mathrm{x}} \mathrm{Co}_{\mathrm{x}} \mathrm{C}$, and h) $\mathrm{Fe}_{2-\mathrm{x}} \mathrm{Co}_{\mathrm{x}}$. 


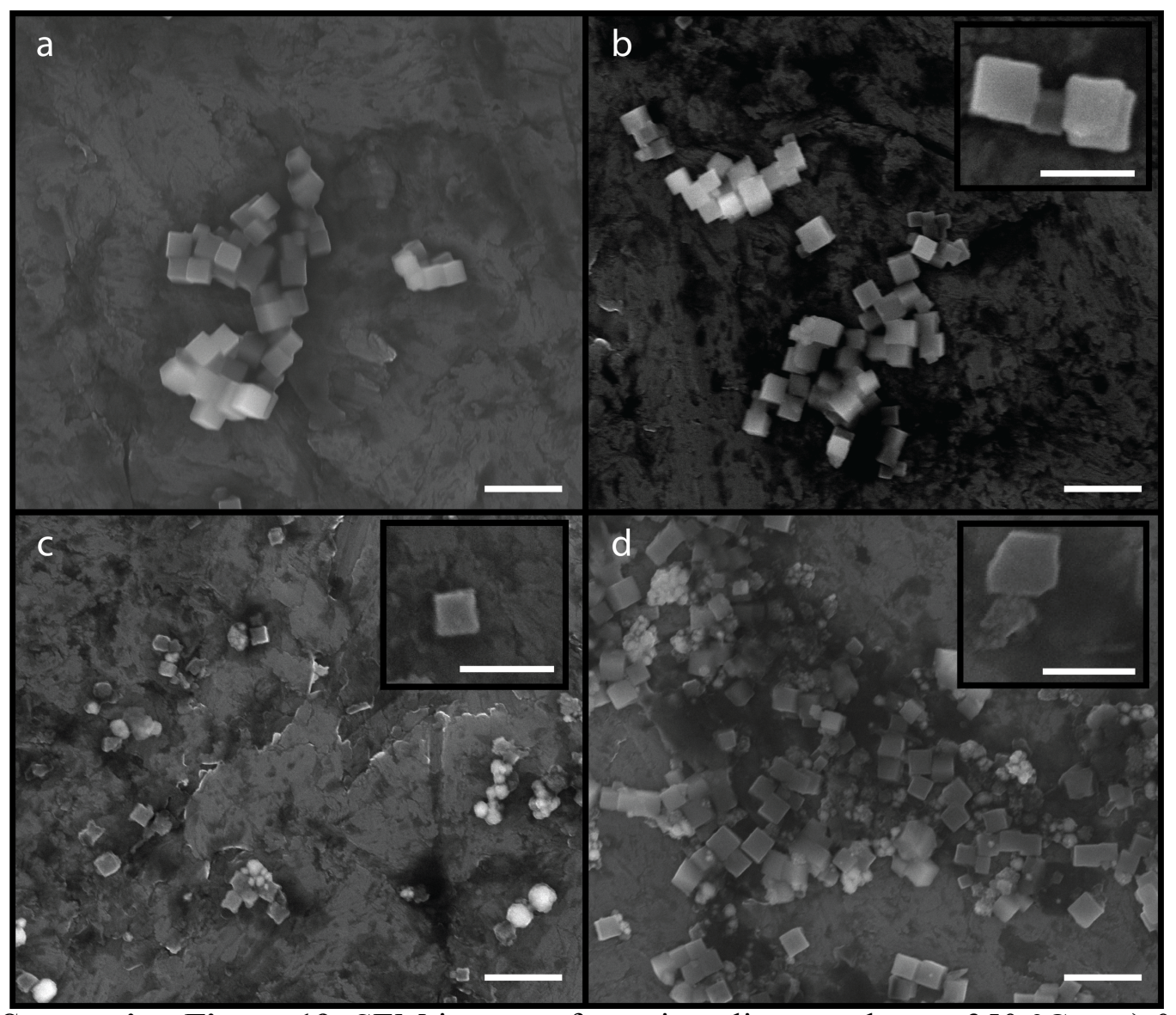

Supporting Figure 19: SEM images of reaction aliquots taken at $350{ }^{\circ} \mathrm{C}$ at a) 0 min, b) $15 \mathrm{~min}$, c) $30 \mathrm{~min}$, and d) $60 \mathrm{~min}$. The scale bars for the main figures are $1,000 \mathrm{~nm}$ while the insets in Figures SI 5b, c, and d, are $500 \mathrm{~nm}$. 

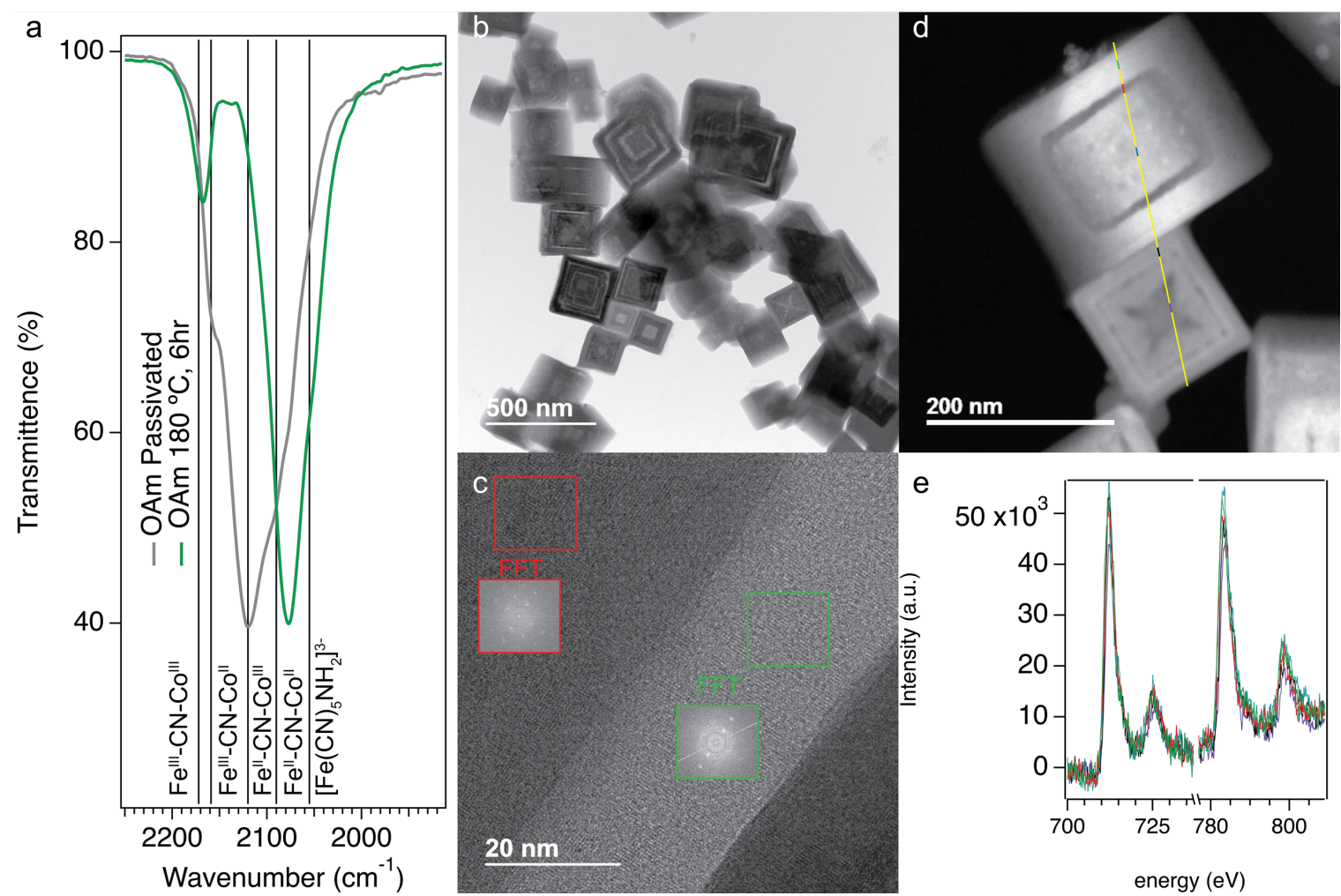

Supporting Figure 20: Characterization of a PBA heated to $180^{\circ} \mathrm{C}$ in OAm for $6 \mathrm{~h}$. a) FTIR characterization of the M-CN stretch showing the weakened M-C bond at $2074 \mathrm{~cm}^{-1}$, evident in the orthorhombic structure. Bright field TEM image (b) and high resolution TEM image showing the FFT of the light and dark regions; both regions are assigned to the orthorhombic structure. e) Dark field TEM image of a PBA cube where the yellow line represents the EELS line scan and f) data from the EELS line scan where the color of the trace represents the area from the line scan. 


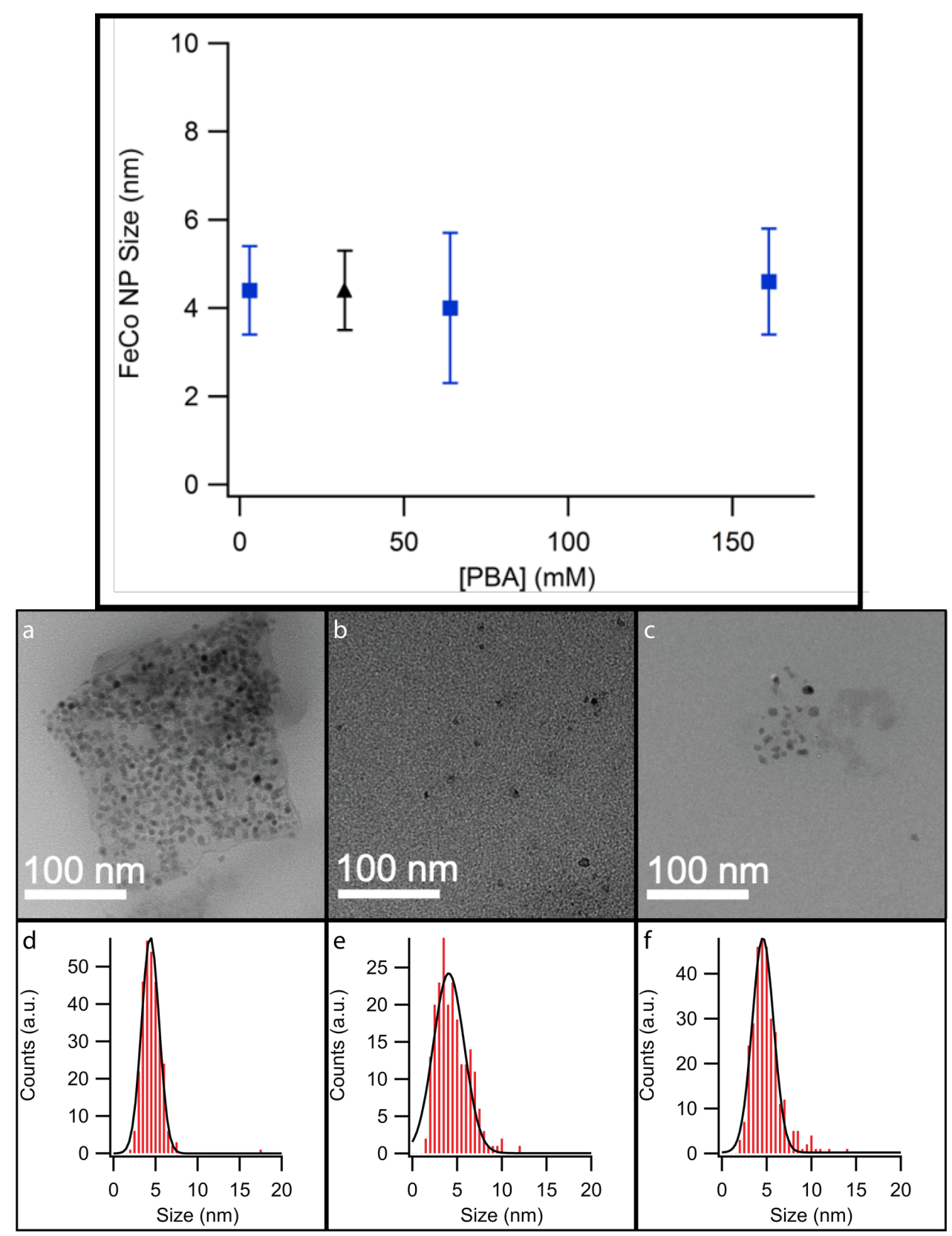

Supporting Figure 21: Reaction concentration vs. resultant nanoparticle size. Black triangle is the original collapse at $32 \mathrm{mM}$ and the blue squares are collapses at 3,64, and $161 \mathrm{mM}$. TEM images of a) $3 \mathrm{mM}$ collapse, b) $64 \mathrm{mM}$ collapse, and c) $161 \mathrm{mM}$ collapse and accompanying histograms in d) $3 \mathrm{mM}$, e) $64 \mathrm{mM}$, and f) $161 \mathrm{mM}$. Statistics were generated by analyzing $>300$ particles. 


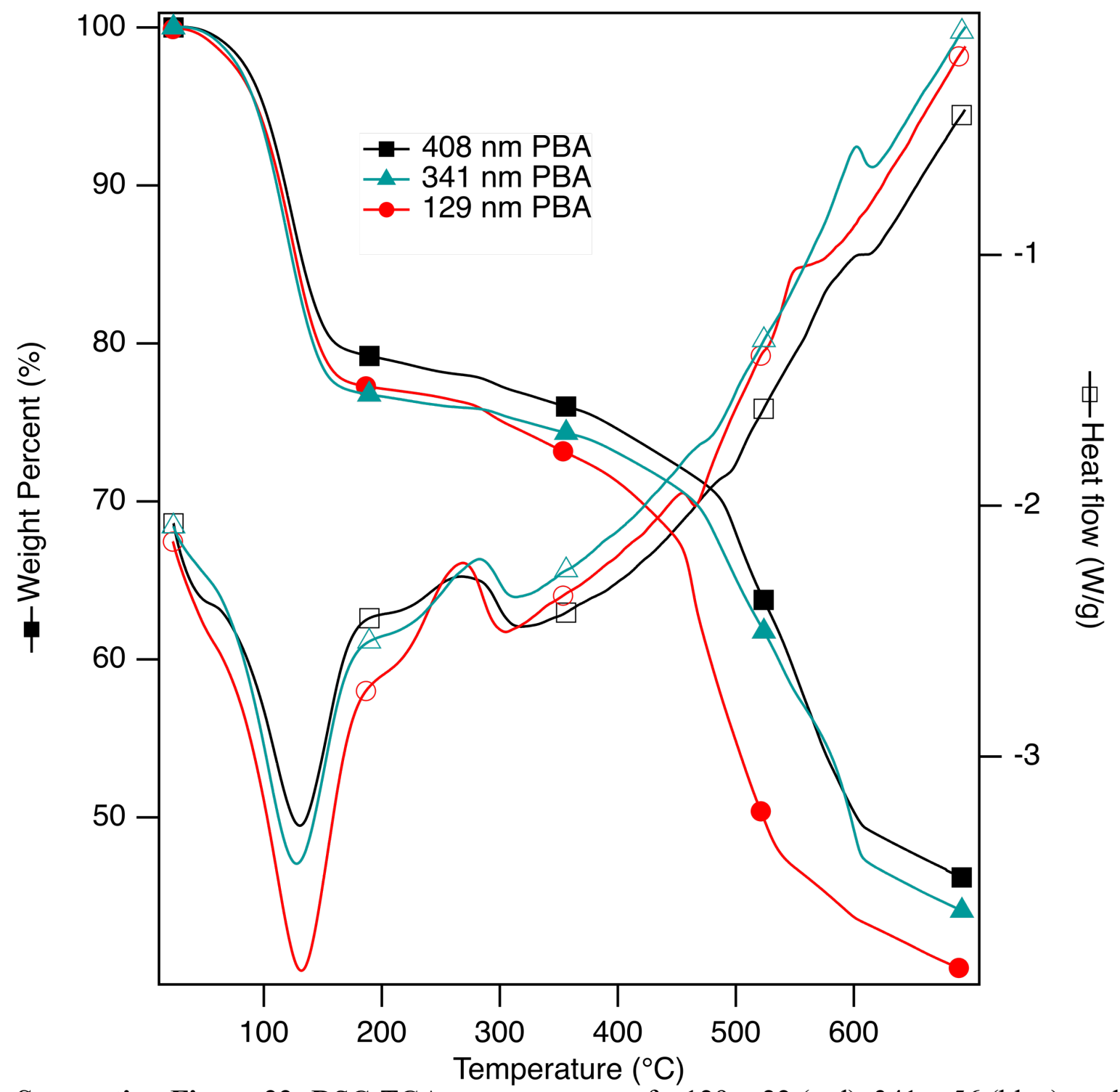

Supporting Figure 22: DSC-TGA measurements of a $129 \pm 22$ (red), $341 \pm 56$ (blue), and $408 \pm 80 \mathrm{~nm}$ (black) $\mathrm{KCo}_{x}\left[\mathrm{Fe}_{2-\mathrm{x}}(\mathrm{CN})_{6}\right]$ Prussian blue analogues. The samples were heated under $\operatorname{Ar}$ at $10{ }^{\circ} \mathrm{C} / \mathrm{min}$. 